\title{
Aptian-Albian coral faunas from the Sierra del Carche (Prebetic, Murcia, southern Spain)
}

\author{
Hannes LÖSER ${ }^{I^{*}}$, Consuelo ARIAS \& Lorenzo VILAS
}

${ }^{1}$ Estación Regional del Noroeste, Instituto de Geología, Universidad Nacional Autónoma de México, Blvd. Luis Donaldo Colosio S/N y Madrid, 83250 Hermosillo, Sonora, México; loeser@paleotax.de

${ }^{2}$ Instituto de Geociencias (CSIC-UCM), Universidad Complutense, 28040 Madrid, Spain; ariasc@geo.ucm.es

${ }^{3}$ Departamento de Estratigrafía-IGEO (CSIC-UCM), Universidad Complutense, 28040 Madrid, Spain; vilasminondo@gmail.com

* Corresponding author

Löser, H., Arias, C. \& Vilas, L. 2015. Aptian-Albian coral faunas from the Sierra del Carche (Prebetic, Murcia, southern Spain). [Faunas de corales del Aptiense-Albiense de la Sierra del Carche (Prebético, Murcia, sur de España)]. Spanish Journal of Palaeontology, 30 (1), 43-64.

\begin{abstract}
Three small coral faunas from the Early Aptian, Latest Aptian and Late Albian from a sedimentary section in the Sierra del Carche are described. A total of 17 species in 15 genera of the suborders Amphiastraeina, Archeocaeniina, Faviina, Fungiina, Heteroceniina, Microsolenina, and Stylinina are reported. One species in the genus Heteropistophyllum is described as new. The Early Aptian fauna encompasses six species, the Late Aptian fauna three species and the Late Albian fauna ten species. The three faunas do almost not share species. There are only colonial corals.
\end{abstract}

Keywords: Cretaceous, taxonomy, invertebrates.

\section{RESUMEN}

Se describen tres pequeñas asociaciones de faunas de corales pertenecientes al Aptiense inferior, Aptiense terminal y Albiense superior de una sección de la Sierra del Carche. En total se han registrado 17 especies en 15 géneros de los subórdenes Amphiastraeina, Archeocaeniina, Faviina, Fungiina, Heteroceniina, Microsolenina y Stylinina. Se describe una nueva especie del género Heteropistophyllum. La fauna del Aptiense inferior abarca seis especies, la del Aptiense superior tres especies y la del Albiense terminal 10 especies. Las tres asociaciones faunísticas prácticamente no comparten especies. Solamente hay corales coloniales.

Palabras clave: Cretácico, taxonomía, invertebrados. 


\section{INTRODUCTION}

Numerous coral faunas are reported from the Early Cretaceous of the Iberian peninsula, but most of them are from Cantabria, the Pyrenees, and Catalonia. Coral faunas from the southern part of the Iberian Peninsula are poorly documented. Particularly, the paleontology of the Prebetic needs more investigation. The investigated area at the Sierra del Carche encompasses a large shallow marine sedimentary section that reaches from the Late Barremian to the Albian. Except for a first sedimentology and stratigraphic review (Masse et al., 1992) not much is published about this area. This is also the case for the corals found in various levels. Although the material is not abundant and partly not in an optimal state of preservation it is worthy description because it encompasses various rare genera and shows interesting paleobiogeographic aspects.

\section{STUDY AREA}

\subsection{Sierra del Carche}

The Sierra del Carche is located in the South-East of Spain (Fig. 1) in the region known as the Jumilla-Yecla Plateau (Murcia). This area is characterized from a geomorphological point of view by wide plain valleys of an average altitude of $600 \mathrm{~m}$ that separate long, narrow mountain ranges that run parallel to those valleys with altitudes above $900 \mathrm{~m}$. Immediately SE of the Jumilla Plateau, the Sierra del Carche shows its large size, standing out from the nearest mountains. It has a slightly elongated shape following SSW-NNE, with a maximum height of $1,350 \mathrm{~m}$. Two wide plains, practically flat, limit the mountain range to the NE and SE; the northern slope shows steep limestone escarpments while the stepped southern face ends in big alluvial fans from the Pliocene or ancient Quaternary ages. Located in the southwest end is an important diapir which cuts at an oblique angle the Cretaceous sediments that shape the massif core. Its northeastern boundary is a big strike-slip fault that separates from the Sierra de las Pansas. Geologically the Sierra del Carche is located in the outer zones of the Betic Cordillera, more precisely in the inner Prebetic (Martín-Chivelet et al., 2002; Vilas et al., 2004), where a sedimentary continuity between Jurassic and Cretaceous ages can be found. The sedimentation was controlled by active tectonic rifting during the Lower Cretaceous and passive margin in the rest of the sedimentation until the Upper Cretaceous period. Since then a compressional tectonic activity can be detected. This mountain range forms an overall complex anticline that comes originally from the filling of a half-graben, its further tectonic inversion and finally strike-slips tectonics. Stratigraphically, the lowest Cretaceous sediments correspond to the Upper Barremian, with a continuous record until and including the Paleocene, although there exists an important hiatus from the Lower

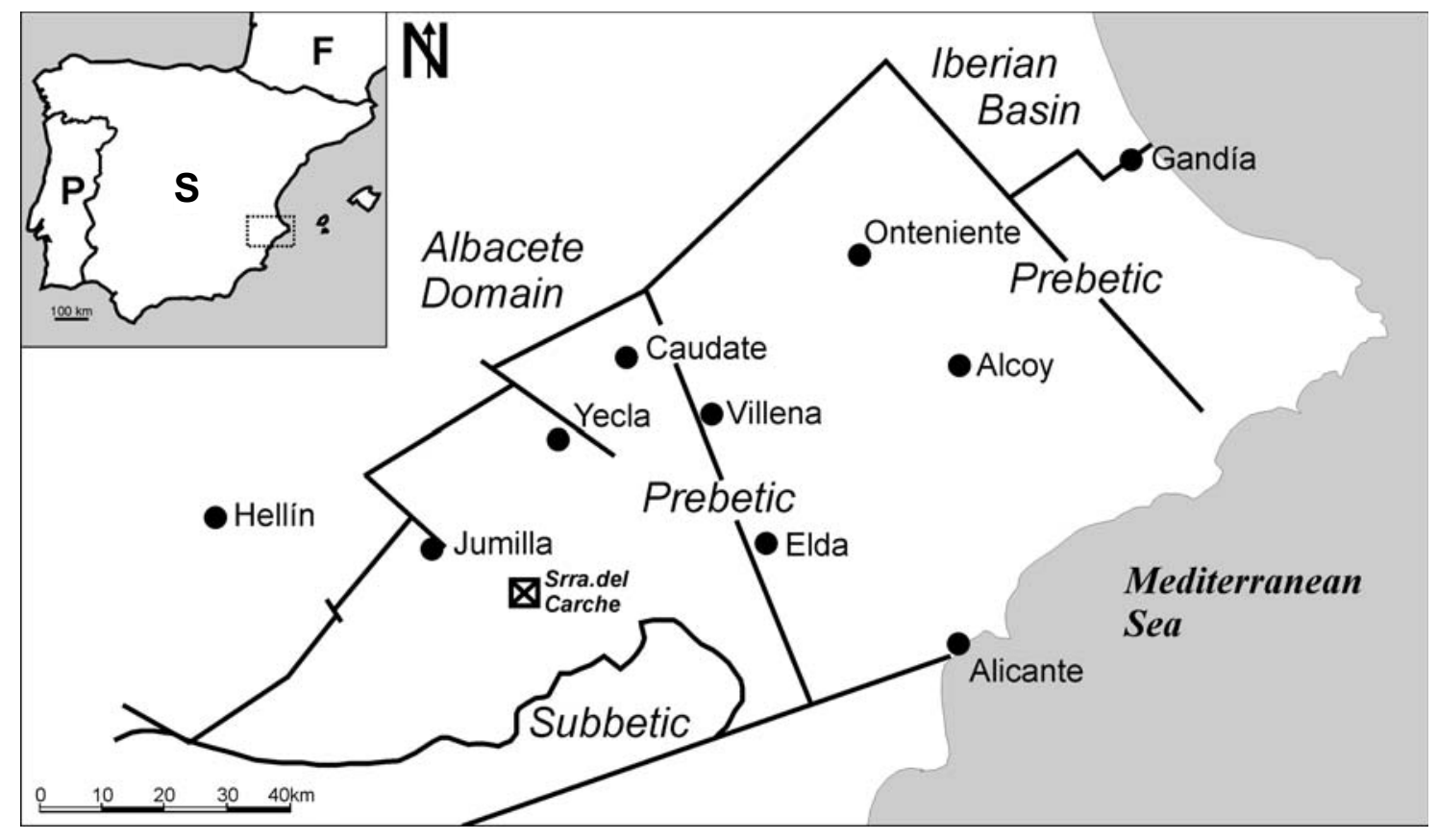

Figure 1. Geographical location of the Sierra del Carche and its position within the major divisions of the Eastern Prebetic (modified from Vilas et al., 2004). 
Cenomanian until the Coniacian that characterizes a palaeographic unit into the Prebetic (Martínez del Olmo et al., 1982; Martín Chivelet, 1993; Vilas et al., 1998, 2005).

\subsection{The stratigraphic section}

The mountain range is formed by the sedimentation of successive carbonate or mixed platforms. The Aptian sediments present a thickness of $550 \mathrm{~m}$ while the Albian and Lower Cenomanian sediments have a thickness of $350 \mathrm{~m}$ (Fig. 2). Regionally, these Cretaceous sediments have been divided into eleven tectosedimentary episodes or sequence sets (K1-K11), five of which correspond to the Lower Cretaceous (K1-K5) with a record of an inner marine platform sedimentation, and six (K6-K11) for the Upper Cretaceous, with a record that varies between hemipelagic sedimentation (dominant toward the top) with episodes of near-shore sediments (Vilas et al., 1998, 2003; Chacón \& Martin-Chivelet, 2003; Martín-Chivelet \& Chacón, 2007).

The K4 megasequence has Lower Aptian age and is divided into three minor-order sequences (K4.1, K4.2 and K4.3). Corals from sample $\mathrm{C} 1$ correspond to the middle part of the K4.1, just below the Iraqia simplex unit. This sequence begins with siliciclastic sediments and ends with a shallow carbonate platform which contains well developed calcarenites under an upper layer of coralbearing limestones that conform the top (as shown in section $\mathrm{C} 1$ of Fig. 2).

Samples $\mathrm{C} 2$ belongs to the K4.3 sequence, specifically to K4.3.2. It is enclosed between the levels containing Orbitolinopsis reticulata Moullade \& Peybernès, 1978 and Orbitolinopsis aquitanica Schroeder \& Poignant, 1964 in its lower part, and Pseudochofatella cuvillieri Deloffre, 1961 in its top. Nodular limestones with abundant corals, rudists and ostreids are supported by well-developed calcarenites (Fig. 2, C2). At the top of these limestones a sedimentary interruption can be seen, and above it siliciclastic sediments start to appear, as a base of the overlying sequence.

The coral samples $\mathrm{C} 3$ and $\mathrm{C} 4$ correspond to the top of unit K6, which belongs to the Upper Albian, and more specifically to the K6.2 sequence, with a thickness of 44 $\mathrm{m}$. From a lithostratigraphic point of view, it belongs to the "Jumilla Formation" defined by Martín-Chivelet (1993, 1994).

The whole Jumilla Formation represents the beginning of the passive margin episode after the end of the "rifting" period of the Early Cretaceous. From a sedimentary evolution standpoint it corresponds to a transgressive period, expansive in the basin, which is formed in successive pulses. This sequence, with typical "Urgonian" characteristics, can be recognized throughout the mountain range although with no physical continuity due to the significant postsedimentary tectonic evolution. Lateral facies changes are frequent. Over predominantly siliciclastic levels, a carbonate platform is installed with a powerful starting level of recrystallized and somewhat dolomitized limestones that probably are originally calcarenites. Above them there are three levels of limestone that form ridges, abundant in rudists, separated by nodular limestones with intense bioturbation, easy to erode. The nodular levels that separate these three limestone levels stand out for their ample bioturbation and a fauna of Radiolitidae and Polyconites at the lower level and colonial and solitary corals at the two upper levels (Fig. 2, C3, C4).

The sequence K6.2 ends in a ferruginous and bioturbated surface upon which the following sequence begins with terrigenous sediments alternating with brown grainstone type of limestone. The abundance of benthic foraminifers in this K6.2 sequence has assisted in dating this level as Upper Albian, but more precise it belongs to a typical biozone of benthic foraminifers that is characterized by the occurrence of Neorbitolinopis conulus (Douvillé, 1912) and Simplorbitolina conulus (Schroeder, 1965). The Aptian and Albian sediments from the Carche Sierra were mainly dated by determining the abundant benthic foraminifera and rudists (Masse et al., 1992).

\section{MATERIALS AND METHODS}

The material comes from four different levels with much variation in coral content (Fig. 2, Table 1). The amount of species is low in most levels, on one hand because of their rarity and the other because of their partly very poor state of preservation. The corals are only presented by small colonies. Most specimens were only superficially preserved and did not allow the preparation of thin sections. Because of this, in many cases only transversal, but no longitudinal thin sections could be prepared. Solitary corals were encountered in the field, but due to their poor state of preservation it was impossible to assign them even to a genus.

Coral slabs and thin sections were examined using a Zeiss STEMI 2000-C stereo microscope. Microphotographs for illustration purposes were obtained using a transparency scanner Epson Perfection V750-M Pro with an optical resolution of 6,400 dots per inch. Calicular dimensions were systematically measured. Values were calculated using the Palaeontological Database System PaleoTax, module PaleoTax/Measure (http://www.paleotax.de/ measure). The procedure and statistical background are described in Löser (2012). The obtained morphometric values on the fossils were compared against those on specimens in World Wide fossil coral collections using a PaleoTax database (Löser, 2004) on Post-paleozoic corals and associated image database (with 21,000 specimens, 
about 9,650 illustrated, located in the Estación Regional de Noroeste, Sonora, Mexico). The material is kept at the collection of the Bayerische Staatsammlungen für Paläontologie und Geologie, München (Germany; BSPG) under the numbers 2014 XV 1 to 36.

Table 1. List of coral species and the corresponding level.

\begin{tabular}{|c|c|c|c|c|}
\hline Bed & C1 & $\mathrm{C} 2$ & $\mathrm{C3}$ & C4 \\
\hline Stratigraphy Species & $\begin{array}{l}\text { Early } \\
\text { Aptian }\end{array}$ & $\begin{array}{l}\text { Early Late } \\
\text { Aptian }\end{array}$ & Late Albian & \\
\hline Actinaraea sp. & & & & $\mathrm{X}$ \\
\hline Amphiastrea sp. & $\mathrm{X}$ & & & \\
\hline Astraeofungia sp. & & & $\mathrm{X}$ & $\mathrm{X}$ \\
\hline Camptodocis sp. & $\mathrm{X}$ & & & \\
\hline Cryptocoenia almerai & & & & $\mathrm{X}$ \\
\hline Cryptocoenia sp. & & & & $\mathrm{X}$ \\
\hline Dimorpharaea sp. & $\mathrm{X}$ & & & \\
\hline Dimorphastrea sp. & & & & $\mathrm{X}$ \\
\hline Diplogyra casanovai & $\mathrm{X}$ & & & \\
\hline Diplogyra lamellosa & & $\mathrm{X}$ & & \\
\hline $\begin{array}{l}\text { Heteropistophyllum } \\
\text { carchensis } \mathrm{n} . \mathrm{sp} .\end{array}$ & & $\mathrm{X}$ & & \\
\hline Ovalastrea picteti & & & $\mathrm{X}$ & \\
\hline $\begin{array}{l}\text { Placocolumastrea } \\
\text { gortanii }\end{array}$ & & & & $\mathrm{X}$ \\
\hline Pleurocoenia aprutina & $\mathrm{X}$ & & & \\
\hline $\begin{array}{l}\text { Silingastraea } \\
\text { shimoheiensis }\end{array}$ & $X$ & $\mathrm{X}$ & $\mathrm{X}$ & \\
\hline Stelidioseris cornueli & & & & $\mathrm{X}$ \\
\hline Stylina inwaldensis & & & & $\mathrm{X}$ \\
\hline
\end{tabular}

\section{SYSTEMATIC PALAEONTOLOGY}

Collection abbreviations are as follows:

BSPG, Bayerische Staatssammlung für Paläontologie und Geologie, München, Germany;

ERNO, Instituto de Geología, Estación Regional de Noroeste, Universidad Nacional Autónoma de México, Hermosillo, Mexico;

FSL, Université Claude Bernard, Institut de Géologie, Lyon, France;

GSUB, Geologisch-Paläontologisches Institut Bremen, Germany;

IGM, Instituto de Geología, Universidad Nacional Autónoma de México, Mexico City, Mexico;

MB, Museum für Naturkunde der Humboldt-Universität, Berlin, Germany;

MGSB, Museo Geológico del Seminario de Barcelona, Spain;

SNSD-MMG, Senckenberg Naturhistorische Sammlungen Dresden, Museum für Mineralogie und Geologie, Dresden, Germany;

TUM, The Tohoku University Museum, Sendai, Japan; ZSH, Zumsteinhaus, Kempten, Germany.

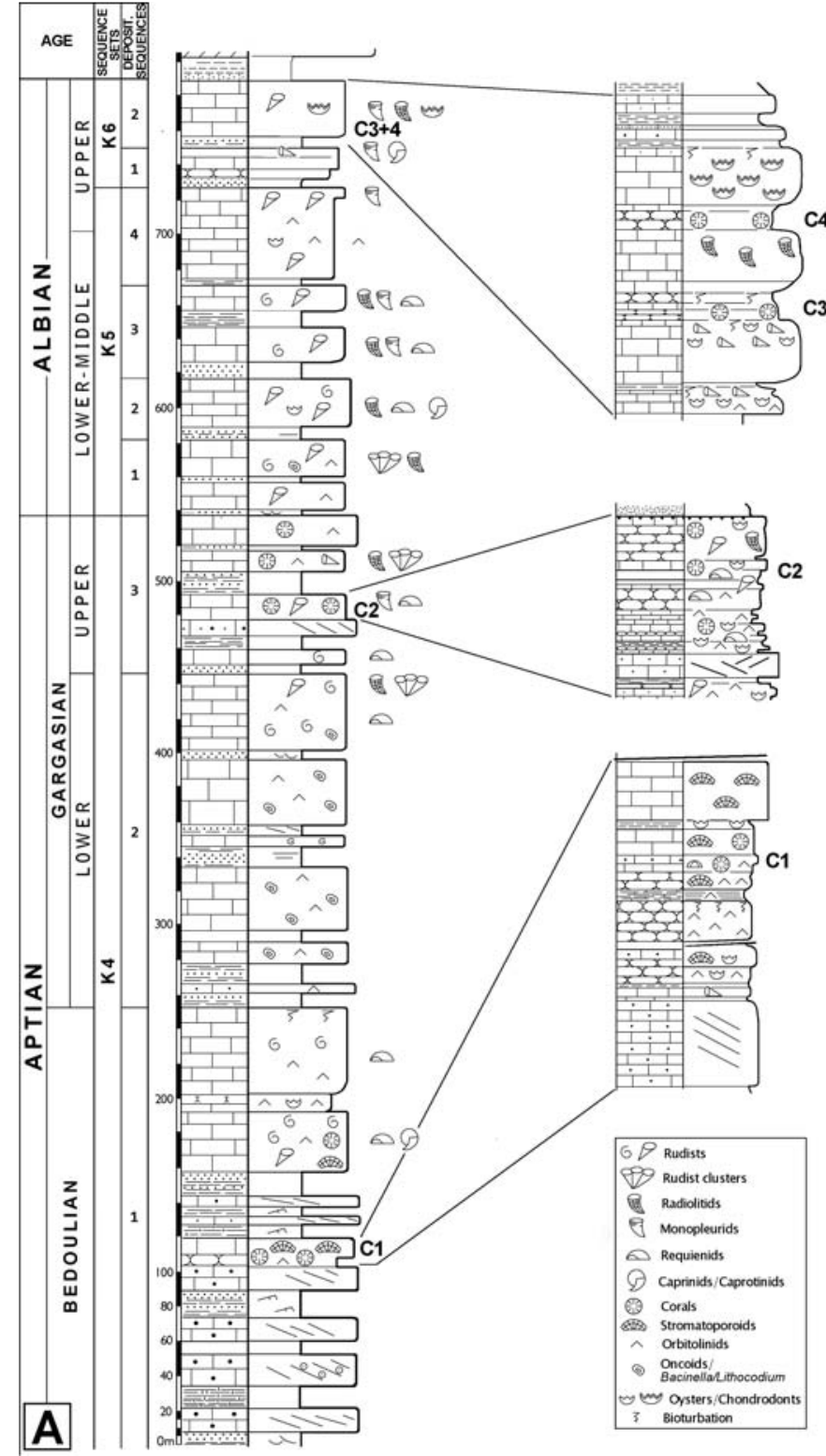

Figure 2. General column of Aptian and Albian sediments from Sierra del Carche and details of the sections where coral samples described in this paper were collected.

The following abbreviations are used describing the dimensions of the corals:

c max, larger outer calicular diameter;

c min, smaller outer calicular diameter;

ccd, distance between calicular centres;

cdw, distance between calicular centres within calicular series;

cl, calicular diameter (calicular pit);

cl max, large lumen;

cl min, small lumen;

crd, distance of calicular series;

crw, width of calicular series;

$\mathrm{s}$, number of radial elements in adult calices;

sd, density of radial elements. 
The abbreviations used in the synonymy lists follow Matthews (1973):

*, earliest valid publication of the species name;

$\mathrm{v}$, the specimen was observed by the first author.

Suborder AMPHIASTRAEINA Alloiteau, 1952 Family Amphiastraeidae Ogilvie, 1897 Amphiastrea Etallon, 1859

Type species. Amphiastrea basaltiformis Etallon, 1859.

Amphiastrea sp.

(Figs 3a-c)

Material. BSPG 2014 XV 1; 2 thin sections.

\section{Dimensions.}

$\begin{array}{lrrrrrr}(2014 \text { XV 1) } & \mathrm{n} & \min -\max & \mu & \mathrm{s} & \mathrm{cv} & \mu \pm \mathrm{s} \\ \mathrm{cl} \min & 30 & 1.04-1.49 & 1.24 & 0.12 & 10.0 & 1.12-1.37 \\ \mathrm{cl} \max & 30 & 1.67-2.26 & 2.01 & 0.17 & 8.7 & 1.83-2.19 \\ \mathrm{ccd} & 20 & 1.78-2.67 & 2.26 & 0.26 & 11.5 & 2.00-2.52 \\ \mathrm{~s} & 7 & 22-33 & 26.42 & 3.69 & 13.9 & 23-30\end{array}$

Description. Cerioid colony. Calicular outline irregular polygonal. Septa compact. Microstructure of septa unknown. Septa in cross section slightly thicker close to the wall, becoming slightly thinner towards the centre. Symmetry of septa bilateral. Cycles of septa irregular, but size orders can be distinguished. Septal generations differ in length and thickness. First septal generation reaches through the centre of the calice, later generations are subsequently shorter. Septa not connected to each other. About three to five main septa present, that are longer than all other septa. Septal distal margin unknown, lateral face unknown, inner margin slightly swollen in places. Pali or paliform lobes absent, lonsdaloid septa,costae, synapticulae and columella absent. Endotheca consists of central tabulae and lateral dissepiments. Wall present, compact, probably trabecular. No marginarium (probably not visible due to the poor preservation). Budding intracalicinal, marginal.

Remarks. The specimen presents very small dimensions and cannot be compared to any existing species. Small dimensions are also shown by Amphiastrea paronai Prever, 1909 and Amphiastraea gracilis Koby, 1888, but their calicular dimensions are still larger. Unfortunately, the poor state of preservation of the present material does not allow the description of a new species.
Occurrence. Sierra del Carche, Early Aptian, bed C1.

Suborder ARCHEOCAENIINA Alloiteau, 1952 Family Actinastraeidae Alloiteau, 1952 Stelidioseris Tomes, 1893

Type species. Stelidioseris gibbosa Tomes, 1893. Stelidioseris cornueli (Orbigny, 1850) (Figs 3d-e)

Material. BSPG 2014 XV 2; 1 thin section.

\section{Synonymy.}

* 1850 Astrocoenia Cornueliana; Orbigny, (2), p. 92

v 1870 Astrocoenia decaphylla; Duncan, p. 29, P1. 11, Figs. 1-6

v 1935 Astrocoenia Cornueliana d'Orb.; Cottreau, Pl. 74, Figs. 6-7

v 1936 Astrocoenia pseudominima Koby 1896; Hackemesser, p. 71, Pl. 7, Fig. 14

v 2009 Actinastrea minima (de Fromentel, 1857); Löser et al., p. 337, Fig. 2.9

v 2013c Actinastrea minima (de Fromentel, 1857); Löser et al., p. 44, Pl. 1, Figs. 3-4

\section{Dimensions.}

$\begin{array}{lcccccc}(2014 \text { XV2) } & \mathrm{n} & \min -\max & \mu & \mathrm{s} & \mathrm{cv} & \mu \pm \mathrm{s} \\ \mathrm{cl} \min & 22 & 1.07-1.52 & 1.34 & 0.13 & 10.0 & 1.21-1.48 \\ \mathrm{ccd} & 20 & 1.60-2.37 & 1.93 & 0.23 & 12.0 & 1.69-2.16 \\ \mathrm{~s} & 10+10 & & & & & \end{array}$

Description. Plocoid colony. Calicular outline circular to slightly elliptical. Septa compact, in cross section thick close to the wall, slightly thinner towards the centre. Septa of the first cycle with swellings (renflements). Symmetry of septa radial and regularly decameral. Cycles of septa regular. Septal cycles differ in length and thickness. First septal cycle reaches to the centre of the calice, the second cycle is much shorter. Septa of the second cycle occasionally attached to those of the first cycle. Septal distal margin unknown, lateral face with fine thorns. Pali or paliform lobes absent. All septa of the first cycle are attached to the columella. Costae hardly present, confluent leaving regular small intercalicinal spaces (lacunes). Synapticulae absent. Columella styliform. Endotheca unknown. Wall compact, septothecal. Coenosteum very narrow, consists of costae. Budding intracalicinal.

Remarks. The syntypes of Astrocoenia cornueliana and Astrocoenia minima Fromentel, 1857 were recently found at the MNHN (Paris). The latter species belongs 

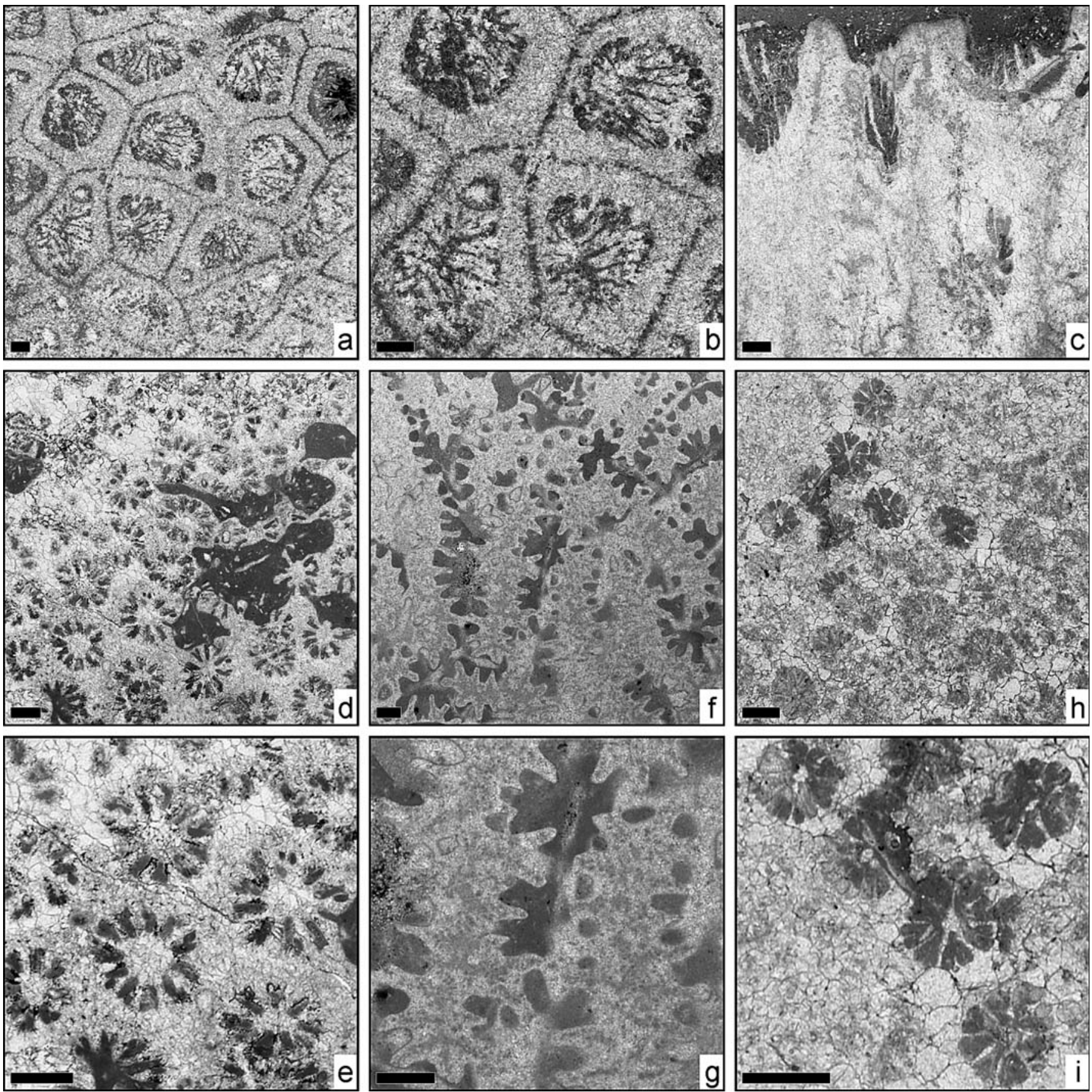

Figure 3. a-c) Amphiastrea sp. (BSPG 2014 XV 1); (a) transversal thin section; (b) transversal thin section, detail; (c) oblique thin section. d-e) Stelidioseris cornueli (Orbigny, 1850), (BSPG 2014 XV 2); (d) transversal thin section; (e) transversal thin section, detail. f-g) Diplogyra casanovai (Reig Oriol, 1994), (BSPG2014 XV 4); (f) transversal thin section; (g) transversal thin section, detail. h-i) Stylina inwaldensis (Ogilvie, 1897), (BSPG 2014 XV 36); (h) transversal thin section; (i) transversal thin section, detail. Scale bar $1 \mathrm{~mm}$.

to the genus Holocoenia and therefore not applied to Stelidioseris samples.

Occurrence. Sierra del Carche, Late Albian, bed C4.

Other occurrences. Cretaceous of Greece (Fokída) Kiona massif, Panourgias. Hauterivian of Jamaica (Saint
Catharine) Benbow Inlier, Copper. Early Hauterivian (Radiatus zone) of France (Haute-Marne) Saint Dizier, France (Yonne) Chenay, France (Yonne) Fontenoy, France (Yonne) Gy-l'Evêque, France (Yonne) Leugny, France (Yonne) Saint-Sauveur, France (Yonne) Venoy. Early to Middle Albian (Mammillatum - Lautus zone) of Greece (Viotía) Levadia, Agia Barbara (ERNO L-5386). UK 
(Devonshire) Exeter, Haldon Hill. Middle Cenomanian of Germany (Bayern) Roßstein-Almen.

Suborder FAVIINA Vaughan \& Wells, 1943

Family Columastraeidae Alloiteau, 1952

Placocolumastrea Reig Oriol, 1989

Type species. Placocolumastrea torallolensis Reig Oriol, 1989.

\section{Placocolumastrea gortanii (Prever, 1909)}

(Figs 4a-c)

Material. BSPG 2014 XV 3; 2 thin sections.

Synonymy.

*v 1909 Ulastraea Gortanii; Prever, p. 91, Pl. 5, Figs. 6, 7

v 1926 Astrocoenia asteriscus Weissermel; Dietrich, p. 96

v 1926 Phyllocoenia sp.; Dietrich, p. 67, Pl. 7, Fig. 1

v 1932 Stephanocoenia (?) guadalupae Wells, n.sp.; Wells, p. 235, Pl. 32, Figs. 8, 9, Pl. 39, Fig. 3

v 2013 ?Placocolumastrea gortanii (Prever, 1909); Löser, p. 8, Figs. 3j-1

\section{Dimensions.}

$\begin{array}{lcccccc}(2014 \times V 3) & \mathrm{n} & \min -\max & \mu & \mathrm{s} & \mathrm{cv} & \mu \pm \mathrm{s} \\ \mathrm{cl} \min & 20 & 2.02-2.49 & 2.27 & 0.13 & 5.9 & 2.14-2.41 \\ \mathrm{ccd} & 20 & 2.31-3.59 & 2.80 & 0.36 & 12.8 & 2.44-3.16 \\ \mathrm{~s} & 24 & & & & & \end{array}$

Description. Plocoid colony. Calicular outline circular. Septa compact, in cross section slightly thicker close to the wall, becoming slightly thinner towards the centre. Symmetry of septa radial and regularly hexameral. Cycles of septa regular. Septal cycles differ in length and thickness. First two septal cycles reach $40 \%$ of the calicular diameter, the third cycle is shorter. Septa of the first cycle occasionally connected to each other in the centre of the calice. Septal distal margin unknown, lateral face occasionally with medium size thorns, inner margin slightly swollen in places. Paliform lobes on the first cycle. Some septa may be attached to the columella. Costae present but short, sub-confluent to non-confluent. Synapticulae absent. Columella lamellar. Endotheca consists of tabulae. Wall sub-compact, parathecal. Coenosteum narrow, consists of costae and exothecal dissepiments. Budding extracalicinal.

Occurrence. Sierra del Carche, Late Albian, bed C4.
Other occurrences. Late Valanginian to Early Aptian of Tanzania (Tanganyika, Mtwara) Likonde Kitutu plateau, Litshihu plateau, Munimbira. Late Barremian to Early Aptian (Sartousi - Weissi zone) of Germany (Bayern) Allgäuer Helvetikum, Falkenberg (ZSH H-KU 793). Late Barremian to Early Aptian (Lenticularis zone) of Mexico (Sonora) Municipio Ures, Cerro de Oro (ERNO L-4321). Early Aptian of Egypt (Shebh Gezirat Sena) Maghara Mt, SE Mansour (GSUB SM01). Italy (Abruzzi, L'Aquila) Monti d'Ocre. Early Aptian (Weissi - Furcata zone) of Tanzania (Tanganyika, Mtwara) Nambawala plateau, Pilepile. Late Aptian (Jacobi zone) of USA (Texas) Comal County, Guadalupe River, Demijohn Bend. Early Albian of Mexico (Sonora) Municipio Ures, Cerro de Oro (ERNO L-4927). Early Albian (Mammillatum zone) of France (Aude) Padern, SE Le Crès. Middle Albian of Mexico (Sonora) Municipio San Pedro de la Cueva, Tepache, Lampazos area (ERNO 2189).

Family Eugyridae Duncan, 1884

Diplogyra Eguchi, 1936

Type species. Diplogyra lamellosa Eguchi, 1936.

Diplogyra casanovai (Reig Oriol, 1994)

(Figs 3f-g)

Material. BSPG 2014 XV 4; 1 thin section.

\section{Synonymy.}

*v 1994 Eugyra casanovai n. sp.; Reig Oriol, p. 34, Pl. 1, Fig. b, Pl. 2, Fig. a

v 2013b Diplogyra casanovai (Reig Oriol, 1994); Löser et al., p. 199, Figs. 3b-c [here more detailed synonymy and occurrence data]

\section{Dimensions.}

$\begin{array}{lcccccc}(2014 \mathrm{XV} 4) & \mathrm{n} & \min -\max & \mu & \mathrm{s} & \mathrm{cv} & \mu \pm \mathrm{s} \\ \text { crw } & 20 & 0.83-1.47 & 1.12 & 0.19 & 17.1 & 0.93-1.31 \\ \text { crd } & 11 & 2.03-2.65 & 2.36 & 0.23 & 10.0 & 2.13-2.60 \\ \text { sd } & 10 / 5 \mathrm{~mm} & & & & & \end{array}$

Description. Meandroid colony. Calicular rows short. Calices indistinct. Septa compact, in cross section thicker close to the wall, thinner towards the centre. Symmetry of septa irregular, but two size orders can be distinguished that differ in length and thickness. First septal generation reaches $40 \%$ of the calicular diameter, the second generation is shorter. Septa not connected to each other. Septal distal margin unknown, lateral face smooth (probably due to preservation), inner margin smooth. Pali or paliform 
lobes absent. Costae present, non-confluent. Synapticulae absent. Columella absent. Endotheca unknown. Wall compact, parathecal. Coenosteum medium broad, consists probably of costae and exothecal dissepiments. Budding intracalicinal, polystomodeal.

Occurrence. Sierra del Carche, Early Aptian, bed C1.

Other occurrences. See Löser et al. (2013b).

Diplogyra lamellosa Eguchi, 1936

(Figs 4d-f)

Material. BSPG 2014 XV 5; 2 thin sections.

\section{Synonymy.}

*v 1936 Diplogyra lamellosa; Eguchi, p. 70, Figs. 3, 3 a v 1951 Diplogyra lamellosa Eguchi; Eguchi, p. 12

v 1971 Diplogyra lamellosa eguchii n. subsp.; Morycowa, p. 81, Text-Fig. 25, Pl. 15, Fig. 1, Pl. 23, Fig. 2 1985 Diplogyra subplanotabulata Sikh., sp. nov.; Sikharulidze, p. 32, Pl. 15, Fig. 2

v 2003 Pseudomyriophyllia carpathica Morycowa, 1971; Baron-Szabo \& González León, p. 198, Fig. 5H

\section{Dimensions.}

$\begin{array}{lcccccc}(2014 \text { XV 5) } & \mathrm{n} & \min -\max & \mu & \mathrm{s} & \mathrm{cv} & \mu \pm \mathrm{s} \\ \mathrm{crw} & 15 & 1.57-2.35 & 1.96 & 0.24 & 12.4 & 1.71-2.20 \\ \mathrm{crd} & 10 & 2.90-3.48 & 3.14 & 0.21 & 6.7 & 2.93-3.35 \\ \mathrm{sd} & 10 / 5 \mathrm{~mm} & & & & & \end{array}$

Description. Meandroid colony. Calicular rows long and sinuous. Calices indistinct. Septa compact, in cross section thicker close to the wall, thinner towards the centre. Symmetry of septa irregular, but two size orders can be distinguished that differ in length and thickness. First septal generation reaches $35 \%$ of the calicular diameter, the second generations is shorter. Septa not connected to each other. Septal distal margin unknown, lateral face rarely with medium size thorns, inner margin smooth. Pali or paliform lobes absent. Costae present, confluent. Synapticulae and columella absent. Endotheca consists of tabulae. Wall compact, parathecal. Coenosteum medium broad, consists of costae and exothecal dissepiments. Budding intracalicinal, polystomodeal.

Occurrence. Sierra del Carche, early Late Aptian, bed $\mathrm{C} 2$.

Other occurrences. Early Barremian of Georgia (Kartli) Ali. Barremian to Early Aptian of Romania
(Suceava) Pojorîta area, Cîmpulung-Moldovenesc, Pietrule Albe. Late Barremian to Early Aptian (Lenticularis zone) of Mexico (Sonora) Municipio Ures, Cerro de Oro. Aptian of Mexico (Puebla) San Juan Raya (IGM R10120). Early Aptian of Greece (Viotía) Arachova (BSPG 2003 XX 5504). Latest Aptian of Japan (Iwate-ken) Shimohei-gun, Tanohata-mura, Haipe and Hiraiga. Early Albian of Mexico (Sonora) Municipio Naco, quarry E Naco (ERNO L-4959).

Family Placosmiliidae Duncan, 1884

Silingastraea Liao, 1982

Type species. Silingastraea xainzaensis Liao, 1982.

Silingastraea shimoheiensis (Eguchi, 1951)

(Figs 4g-i)

Material. BSPG 2014 XV 6 - 10; 3 thin sections.

\section{Synonymy.}

$*_{\mathrm{v}} 1951$ Thigmastrea ? shimoheiensis Eguchi, n.sp.; Eguchi, p. 14, Pl. 4, Figs. 1, 2

\section{Dimensions.}

\begin{tabular}{lcrcccr}
$(2014$ XV 10) & $\mathrm{n}$ & $\min -\max$ & $\mu$ & $\mathrm{s}$ & $\mathrm{cv}$ & \multicolumn{1}{c}{$\mu \pm \mathrm{s}$} \\
$\mathrm{ccd}$ & 20 & $4.11-10.12$ & 7.29 & 1.62 & 22.2 & $5.67-8.92$ \\
$\mathrm{~s}$ & 15 & $18-30$ & 24.46 & 3.58 & 14.6 & $21-28$ \\
$\mathrm{sd}$ & $9 / 5 \mathrm{~mm}$ & & & & &
\end{tabular}

Description. Astreoid colony. Calicular outline circular to elliptical, in places arranged in rows. Septa compact. Microstructure of large trabeculae. Septa in cross section centrally thicker. Symmetry of septa irregular, but two to three size orders can be distinguished that differ in length and thickness. First septal generation reaches close to the calicular centre, later generations are shorter. Septa rarely connected to each other in the centre of the calice. Septal distal margin unknown, lateral face with vertical keels, inner margin smooth. Pali or paliform lobes absent. Septa are not attached to the columella. Costae present, non-confluent. Synapticulae absent. Columella lamellar. Endotheca consists of numerous and regular tabulae. Wall absent. Coensteum poorly defined because of the type of the calicular arrangement. Coenosteum consists of costae and tabulae. Budding intracalicinal, polystomodeal and complete.

Remarks. This species is the only one that could be found in all three units. Generally, the genus is very rare in the Western Tethys. 

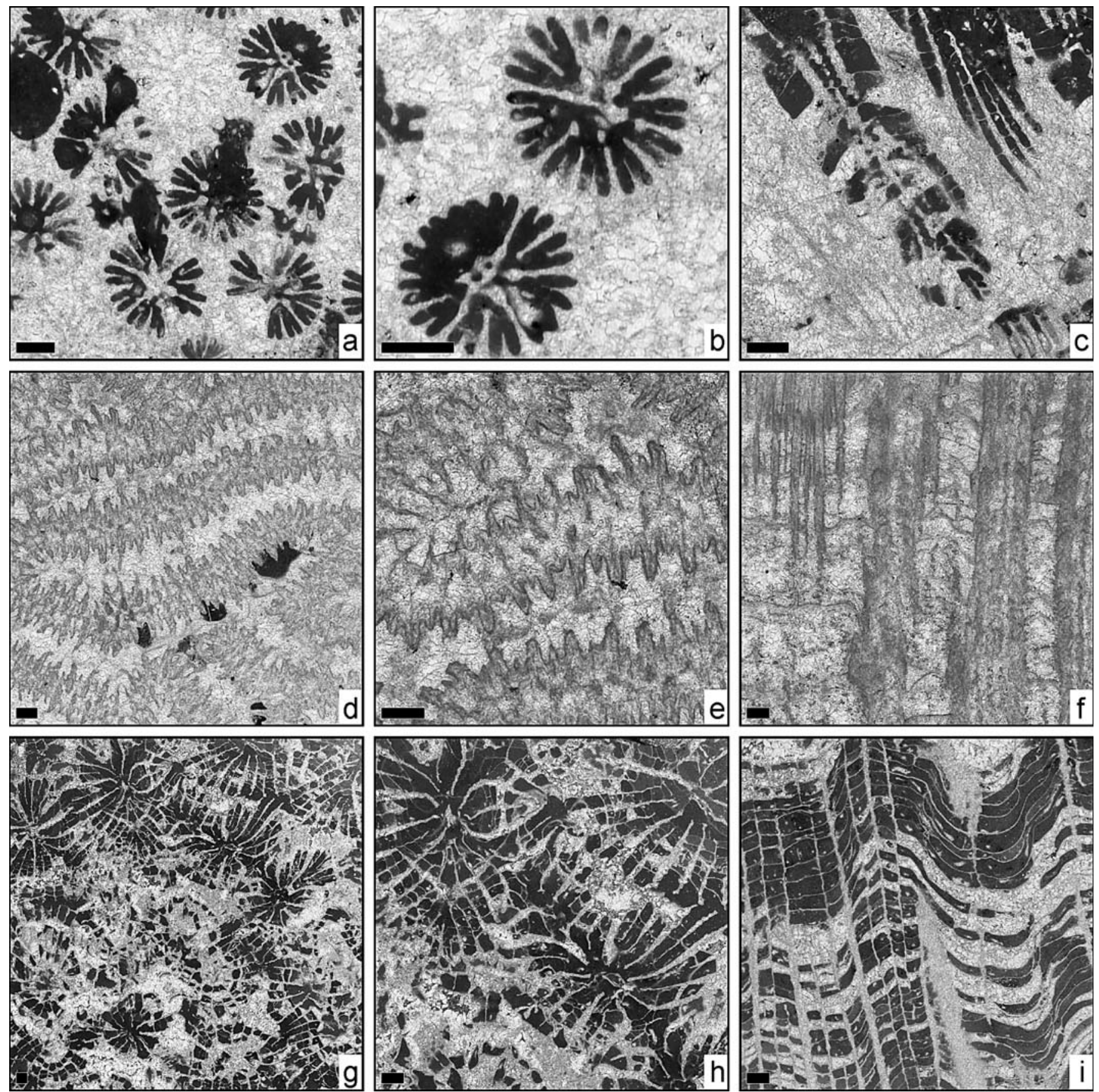

Figure 4. a-c) Placocolumastrea gortanii (Prever, 1909), (BSPG 2014 XV 3); (a) transversal thin section; (b) transversal thin section, detail; (c) longitudinal thin section. d-f) Diplogyra lamellosa Eguchi, 1936, (BSPG 2014 XV 5); (d) transversal thin section; (e) transversal thin section, detail; (f) longitudinal thin section. g-i) Silingastraea shimoheiensis (Eguchi, 1951), (BSPG 2014 XV 10); (g) transversal thin section; (h) transversal thin section, detail; (i) longitudinal thin section. Scale bar $1 \mathrm{~mm}$.

Occurrence. Sierra del Carche, Early Aptian to Late Albian, beds C1, C2, C3.

Other occurrences. Early Aptian of Greece (Viotía) Arachova (MB K624). Latest Aptian of Japan (Iwateken) Shimohei-gun, Taro-cho, Todana Early Cenomanian of Greece (Kozani) Kozani, Nea Nikopolis (BSPG 2003 XX 5828).
Suborder FUNGIINA Verrill, 1868-70

Family Haplaraeidae Vaughan \& Wells, 1943

Actinaraea Orbigny, 1849

Type species. Agaricia granulata Münster in Goldfuss, 1829. 
Actinaraea sp.

(Figs 5a-c)

Material. BSPG 2014 XV 11; 2 thin sections.

Dimensions.
\begin{tabular}{lcrcccr} 
2014 XV 11) & $\mathrm{n}$ & $\min -\mathrm{max}$ & \multicolumn{1}{c}{$\mu$} & $\mathrm{s}$ & $\mathrm{cv}$ & \multicolumn{1}{c}{$\mu \pm \mathrm{s}$} \\
ccd & 7 & $6.16-8.29$ & 6.95 & 0.69 & 9.9 & $6.25-7.64$ \\
$\mathrm{~s}$ & 6 & $49-64$ & 59.33 & 5.92 & 9.9 & $53-65$ \\
$\mathrm{sd}$ & $7 / 2 \mathrm{~mm}$ & & & & &
\end{tabular}

Description. Thamnasterioid colony. Septa regularly perforated. Microstructure of large trabeculae. Septa in cross section equal in thickness in the whole septum. Symmetry of septa irregular, but septal generations that differ in length. Half of all septa extended close to the calicular centre. Septa occasionally connected to each other close to the centre of the calice. Septal distal margin coarsely granulated, lateral face with thorns, inner margin smooth. Pali or paliform lobes absent. Costae present, confluent. Synapticulae abundant. Columella poorly defined, probably represented by one isolated trabecula. Endotheca consists of few tabulae. Wall absent. Coensteum poorly defined because of the type of the calicular arrangement. Budding intracalicinal, polystomodeal and complete.

Remarks. This specimen has - compared to known Actinaraea species - very large dimensions. The only specimen, even if well preserved, did not allow the creation of a new species.

Occurrence. Sierra del Carche, Late Albian, bed C4.

Other occurrences. Aptian of Mexico (Puebla) San Juan Raya, Barranca Agua del Burro (ERNO L-R11703). Early Albian of Mexico (Baja California) Santo Tomás, Arroyo de la Cueva (ERNO L-135106).

Camptodocis Dietrich, 1926

Type species. Camptodocis brancai Dietrich, 1926.

Camptodocis sp.

(Figs 5d-f)

Material. BSPG 2014 XV 12 - 14; 6 thin sections.

Synonymy.

v 2003 Mesomorpha ornata Morycowa, 1971; BaronSzabo \& González León, p. 200, Fig. 5F v 2010 Camptodocis cf. basiplana (Dietrich, 1926); Löser, p. 586, Fig. 2.7

\section{Dimensions.}

\begin{tabular}{lcrcccr}
$(2014 \mathrm{XV} 12)$ & $\mathrm{n}$ & $\min -\mathrm{max}$ & $\mu$ & $\mathrm{s}$ & $\mathrm{cv}$ & \multicolumn{1}{c}{$\mu \pm \mathrm{s}$} \\
$\mathrm{ccd}$ & 15 & $2.25-5.01$ & 3.77 & 0.80 & 21.3 & $2.97-4.58$ \\
$\mathrm{~s}$ & 10 & $17-22$ & 19.40 & 1.71 & 8.8 & $18-21$ \\
$\mathrm{sd}$ & $6 / 2 \mathrm{~mm}$ & & & & &
\end{tabular}

Description. Thamnasterioid colony. Septa irregularly perforated, in cross section equal in thickness in the whole septum. Cycles of septa irregular, size orders can hardly be distinguished. Septal generations differ in length. First septal generation reaches to the centre of the calice, later generations are subsequently shorter. Septa occasionally connected to each other. Septal lateral face occasionally with granulae. Pali or paliform lobes absent. Synapticulae not very common, mainly between the calices but without forming any wall like structure. Columella small, substyliform or lamellar. Endotheca consists of numerous large and thin tabulae. Wall absent. Budding extracalicinal.

Occurrence. Sierra del Carche, Early Aptian, bed C1.

Other occurrences. Barremian (Moutoniceras - Giraudi zone) of France (Drôme) Serre de Bleyton. Late Aptian of Spain (Valencia, Castellón) Benicasin, La Venta (MGSB 73704). Early Albian of Mexico (Sonora) Municipio Ures, Cerro de Oro.

Suborder HETEROCOENIINA Beauvais, 1974

Family Elasmocoeniidae Duncan, 1884

Heteropistophyllum Löser et al., 2013a

Type species. Pseudopistophyllum quinqueseptatum Turnšek \& Buser, 1976.

Heteropistophyllum carchensis n.sp. (Figs 6a-f)

Derivatio nominis. After the type locality.

Holotype. BSPG 2014 XV 15.

Paratypes. BSPG 2014 XV 16, 2014 XV 17.

Material. Six specimens (BSPG 2014 XV 15 to 20) with 8 thin sections.

Diagnosis. Heteropistophyllum with large calices (smaller outer diameter 3.1-4.3 mm, larger outer diameter 5.9-7.1 $\mathrm{mm}$ ), five well developped septa in the smaller 

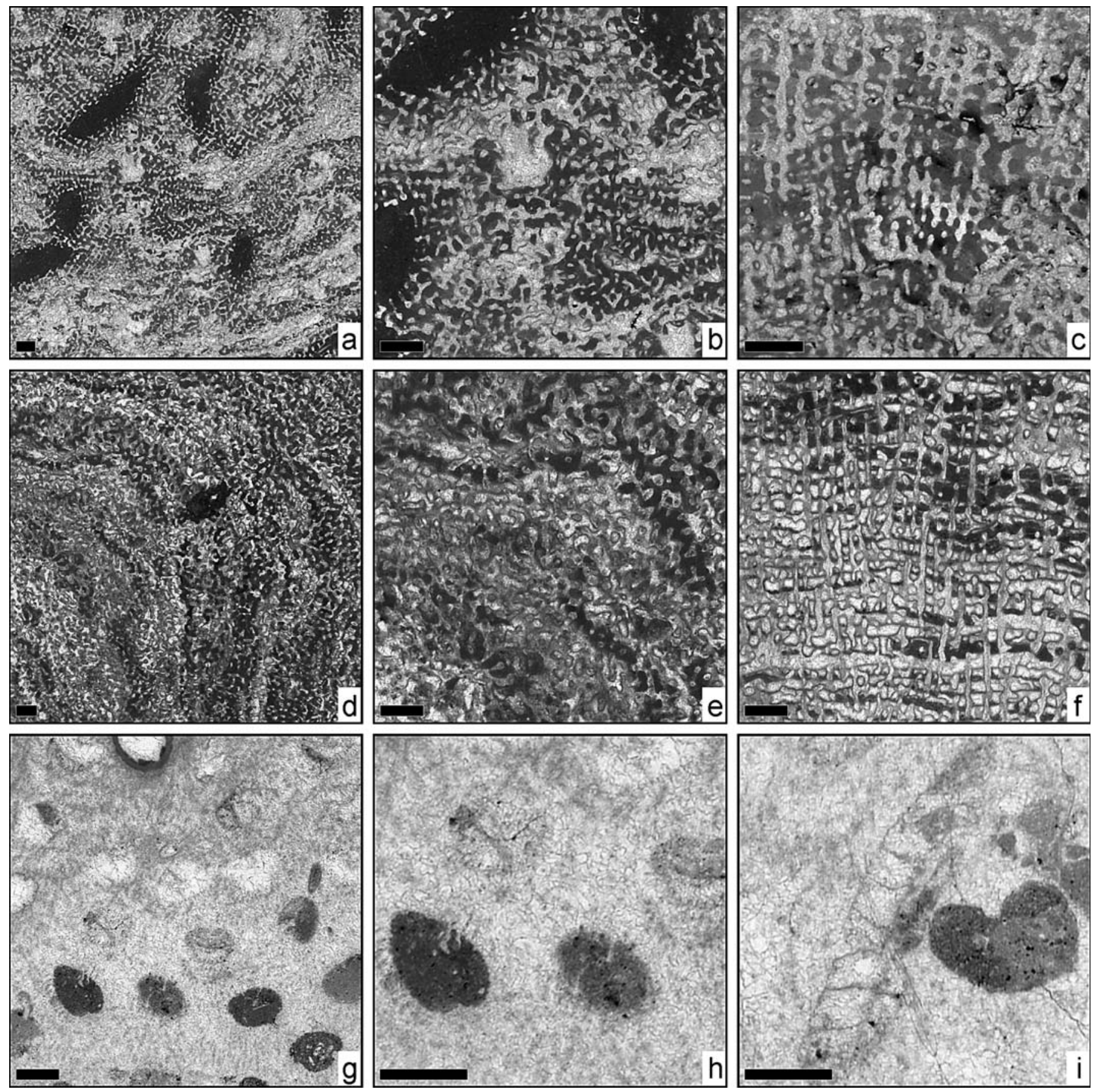

Figure 5. a-c) Actinaraea sp. (BSPG 2014 XV 11); (a) transversal thin section; (b) transversal thin section, detail; (c) longitudinal thin section. d-f) Camptodocis sp. (BSPG 2014 XV 12); (d) transversal thin section; (e) transversal thin section, detail; (f) longitudinal thin section. g-i) Pleurocoenia aprutina (Prever, 1909), (BSPG 2014 XV 21); (g) transversal thin section; (h) transversal thin section, detail; (i) longitudinal thin section. Scale bar $1 \mathrm{~mm}$.

face of the calice, and only septal spines in the larger face of the calice.

Locus typicus. Spain, Murcia, Sierra del Carche, bed $\mathrm{C} 2 ; 38^{\circ} 26^{\circ} 0^{\prime \prime} \mathrm{N} 11^{\prime} 10^{‘} 39.6^{\prime \prime} \mathrm{W}$ (WGS 84).

Stratum typicum. Early Late Aptian.
Comparison. The new species differs from the other known species (H. quinqueseptata Turnšek \& Buser, 1976, H. triseptum Kolodziej et al. 2012) by its large calicular dimensions. H. triseptum shows moreover only three septa.

Remarks. Within the study area, the new species is restricted to one bank, but is common within this bank. 
Apart from this, the new species was only found in the Early Albian of Sonora (Northern Mexico).

\section{Dimensions.}

$\begin{array}{lcccccc}(2014 X V 15) & \mathrm{n} & \min -\max & \mu & \mathrm{s} & \mathrm{cv} & \mu \pm \mathrm{s} \\ \mathrm{cl} \min & 17 & 1.52-2.42 & 1.96 & 0.30 & 15.6 & 1.66-2.27 \\ \mathrm{cl} \max & 17 & 3.44-4.89 & 4.22 & 0.41 & 9.8 & 3.81-4.64 \\ \mathrm{cmin} & 20 & 2.83-5.02 & 3.68 & 0.63 & 17.2 & 3.05-4.32 \\ \mathrm{cmax} & 20 & 5.18-7.34 & 6.45 & 0.59 & 9.2 & 5.85-7.05 \\ \mathrm{~s} & 5 & & & & & \end{array}$

Description. Phaceloid colony. Calicular outline kidney or bean shaped. Septa compact. Symmetry of septa bilateral. General five large septa are located in the smaller face of the calice. They are in cross section thick close to the wall, thinner towards the centre, reaching $60 \%$ of the calicular diameter, and not being connected to each other. Septal distal margin unknown, lateral face with thorns, inner margin slightly swollen in places. Oposite septa are only present as very fine thorns. Pali or paliform lobes, costae, synapticulae and columella absent. Endotheca consists of very few tabulae. Wall thick and compact, probably trabecular. Coenosteum absent. Budding intracalicinal, marginal.

Occurrence. Sierra del Carche, Early Late Aptian, bed $\mathrm{C} 2$.

Other occurrences. Early Albian of Mexico (Sonora) Municipio Arizpe, Arizpe, Cerro La Ceja (ERNO L-4266), Municipio Cucurpe, Cucurpe, La Mesa (ERNO L-4282).

\section{Pleurocoenia Orbigny, 1849}

Type species. Pleurocoenia provincialis Orbigny, 1849.

Remarks. Pleurocoenia differs from Latusastrea Orbigny, 1849 by a reduced coenosteum, only one (rarely three) main septa and secondary septa reduced to spines. Moreover, the calicular dimensions of Pleurocoenia are much smaller than in Latusastrea. Latusastrea ranges from the Late Jurassic into the Early Albian; Pleurocoenia ranges from the Hauterivian to the Turonian.

Pleurocoenia aprutina (Prever, 1909)

(Figs 5g-i)

Material. BSPG 2014 XV 21; 2 thin sections.

\section{Synonymy.}

*v 1909 Heliopora aprutina; Prever, p. 65, Pl. 27, Fig. 1

v 1964 Latusastraea provincialis (Orbigny, 1850); Morycowa, p. 70, Pl. 19, Fig. 3, Pl. 20, Fig. 4

1993 Latusastraea decipiens Prever 1909; BaronSzabo, p. 157, Pl. 2, Fig. 4

1995 Latusastraea exiguis (Fromentel, 1862); Morycowa, Decrouez \& Schenk, p. 18, Figs. 1, 2, 3 a-f

v 1997 Pleurocora sp.; Baron-Szabo, p. 77

v 2006 Latusastrea cf. provincialis (Orbigny, 1849); Löser \& Ferry, p. 480, Figs. 4.6, 4.7

\section{Dimensions.}

$\begin{array}{lcccccc}(2014 \times V 21) & \mathrm{n} & \min -\max & \mu & \mathrm{s} & \mathrm{cv} & \mu \pm \mathrm{s} \\ \text { cl min } & 20 & 0.80-0.96 & 0.88 & 0.04 & 5.3 & 0.83-0.92 \\ \operatorname{cl} \max & 20 & 0.93-1.55 & 1.22 & 0.14 & 11.7 & 1.07-1.36 \\ \mathrm{ccd} & 20 & 1.47-2.24 & 1.82 & 0.25 & 13.8 & 1.57-2.07\end{array}$

Description. Plocoid colony. Calicular outline elliptical. Symmetry of septa bilateral. Main septum in cross section equal in thickness in the whole septum. Septal lateral face occasionally with thorns, inner margin slightly swollen in places. Secondary septa as fine and very short thorns. Pali or paliform lobes, costae, synapticulae, columella absent. Endotheca consists of tabulae. Wall compact, probably trabecular. Coenosteum medium broad, trabecular. Budding extracalicinal.

Occurrence. Sierra del Carche, Early Aptian, bed C1.

Other occurrences. Late Barremian of France (Ardèche) St.Remèze, Belvédère du Serre-de-Tourre. Late Barremian to Early Aptian of Switzerland (Bern) Rawil pass. Aptian of Mexico (Puebla) Tehuacán, Barranco San Lucas (ERNO L-7116). Early Aptian (Tuarkyricus - Weissi zone) of France (Vaucluse) Sault (FSL R72). Early Aptian of Greece (Viotía) Levadia, Perachorion (BSPG 2003 XX 5775). Italy (Abruzzi, L‘Aquila) Monti d'Ocre. Poland (Malopolskie, Wadowice) Lanckorona, Jastrzebia (ERNO L-5427). Latest Aptian to Early Albian of Spain (Vascongadas, Vizcaya) Gamecho, Playa de Laga. Early Albian of Mexico (Sonora) Municipio Opodepe, Tuape, Cerro de la Espina (ERNO L-4459). Late Turonian to Early Coniacian of Austria (Tirol) Brandenberg, Haidach.

Suborder MICROSOLENINA Morycowa \& Roniewicz, 1995

Family Leptophylliidae Vaughan, 1905

Astraeofungia Alloiteau, 1952 

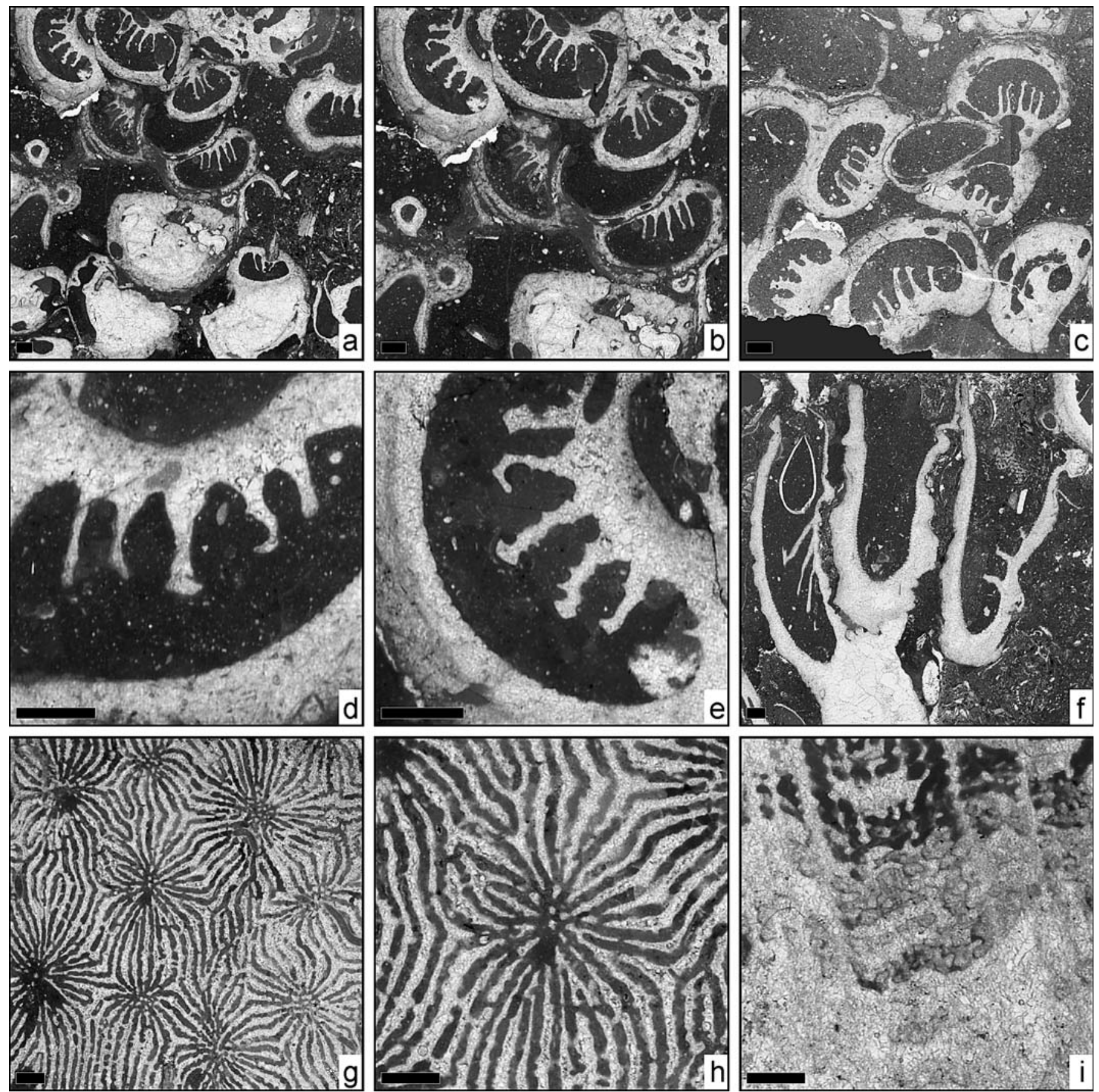

Figure 6. a-f) Heteropistophyllum carchensis n. sp. (BSPG 2014 XV 15, holotype); (a) transversal thin section; (b-e) transversal thin section, detail; (f) longitudinal thin section. g-i) Astraeofungia sp. (BSPG 2014 XV 25); (g) transversal thin section; (h) transversal thin section, detail; (i) longitudinal thin section. Scale bar $1 \mathrm{~mm}$.

Type species. Astrea decipiens Michelin, 1841.

Astraeofungia sp.

(Figs 6g-i)

Material. BSPG 2014 XV 22 - 25; 4 thin sections.

\section{Dimensions.}

\begin{tabular}{lcrcccr}
$(2014 \times V 25)$ & $\mathrm{n}$ & $\min -\max$ & $\mu$ & $\mathrm{s}$ & $\mathrm{cv}$ & \multicolumn{1}{c}{$\mu \pm \mathrm{s}$} \\
$\mathrm{ccd}$ & 25 & $3.07-4.47$ & 3.73 & 0.41 & 11.1 & $3.31-4.14$ \\
$\mathrm{~s}$ & 10 & $22-45$ & 32.70 & 6.53 & 19.9 & $26-39$ \\
$\mathrm{sd}$ & $8 / 2.5 \mathrm{~mm}$ & & & & &
\end{tabular}


Description. Thamnasterioid colony. Septa perforated at their inner margin. Microstructure of large trabeculae. Septa in cross section thick close to the wall, thinner towards the centre. Symmetry of septa irregular. Half of all septa extended close to the calicular centre. Septa often connected to each other close to the centre of the calice. Septal distal margin unknown, lateral face with pennulae and thorns, inner margin smooth. Pali or paliform lobes absent. Costae present, confluent or sub-confluent. Synapticulae occasional, mainly in the space between calices. Columella composed of a group of isolated trabeculae. Endotheca consists of few thin tabulae. Wall absent. Coenosteum poorly defined because of the type of the calicular arrangement. Budding extracalicinal.

Remarks. The material is only comparable to the Late Jurassic Thamnasteria huzimotoi Eguchi, 1951.

Occurrence. Sierra del Carche, Late Albian, bed C3, C4.

Other occurrences. Early Albian (Tardefurcata zone) of Spain (Cataluña, Barcelona) Com. Alt Penedès, Castellvi de la Marca, Can Pascual (BSPG 2003 XX 6284). Early Late Albian (Inflatum zone) of Spain (Valencia, Alicante) Sierra de Llorençá (MGSB 74365). Middle to Late Cenomanian (Rhotomagense - Naviculare zone) of France (Sarthe) Le Mans (MB K3241.2).

\section{Dimorphastrea Orbigny, 1850}

Type species. Dimorphastrea grandiflora Orbigny, 1850.

\section{Dimorphastrea $\mathrm{sp}$.}

(Figs 7a-c)

Material. BSPG 2014 XV 26 - 28; 2 thin sections.

\section{Synonymy.}

v 2013c Dimorphastrea regularis (de Fromentel, 1857); Löser et al., p. 60, Pl. 6, Figs. 5, 6

\section{Dimensions.}

$\begin{array}{lcrcccc}(2014 \text { XV 28) } & \mathrm{n} & \min -\max & \mu & \mathrm{s} & \mathrm{cv} & \mu \pm \mathrm{s} \\ \mathrm{crd} & 4 & 3.84-5.46 & 4.61 & 0.70 & 15.3 & 3.90-5.32 \\ \mathrm{cdw} & 10 & 1.96-3.90 & 2.82 & 0.55 & 19.5 & 2.27-3.37 \\ \mathrm{~s} & 10 & 26-35 & 30.70 & 3.09 & 10.0 & 28-34 \\ \mathrm{sd} & 8 / 2.5 \mathrm{~mm} & & & & & \end{array}$

Description. Thamnasterioid colony with calices arranged in regular rows. Septa perforated at their inner margin. Microstructure of large trabeculae. Septa in cross section thick close to the wall, thinner towards the centre. Symmetry of septa irregular. Half of all septa extended close to the calicular centre. Septa occasionally connected to each other close to the centre of the calice. Septal distal margin unknown, lateral face with pennulae and thorns, inner margin smooth. Pali or paliform lobes absent. Costae present, confluent. Synapticulae occasional, mainly in the space between the calicular centres. Columella composed of a group of isolated trabeculae. Endotheca consists of thin tabulae. Wall absent. Coenosteum poorly defined because of the type of the calicular arrangement. Budding extracalicinal.

Occurrence. Sierra del Carche, Late Albian, bed C4.

Other occurrences. Early Cenomanian (Dixoni zone) of Germany (Sachsen) Meißen-Zscheila, Trinitatis church (SNSD-MMG SaKL 362). Middle Cenomanian of Germany (Bayern) Roßstein-Almen. Late Cenomanian (Plenus zone) of Germany (Sachsen) Dresden-Plauen, Ratssteinbruch (ERNO L-6137).

Ovalastrea Orbigny, 1849

Type species. Astrea caryophylloides Goldfuss, 1826. Ovalastrea picteti (Koby, 1897)

(Figs 7d-f)

Material. BSPG 2014 XV 29 - 31; 4 thin sections.

\section{Synonymy.}

$*_{\mathrm{v}} 1897$ Phyllocoenia ? Picteti; Koby, p. 34, Pl. 10, Fig. 9, 10

v 1951 Montastrea nipponica Eguchi, n.sp.; Eguchi, p. 25, Pl. 5, Fig. 4, 5

v 2013a Ovalastrea picteti (Koby 1897); Löser et al., p. 25, Pl. 8, Fig. 4-6

\section{Dimensions.}

$\begin{array}{lcrcccc}(2014 \text { XV 29) } & \mathrm{n} & \min -\max & \mu & \mathrm{s} & \mathrm{cv} & \mu \pm \mathrm{s} \\ \mathrm{cl} \min & 10 & 1.41-2.09 & 1.77 & 0.23 & 13.1 & 1.53-2.00 \\ \mathrm{cl} \max & 10 & 1.76-2.71 & 2.30 & 0.29 & 13.0 & 2.00-2.60 \\ \mathrm{ccd} & 10 & 2.40-3.49 & 2.81 & 0.33 & 11.9 & 2.47-3.15 \\ \mathrm{~s} & 5 & 31-39 & 34.0 & 3.0 & 8.8 & 31-37\end{array}$



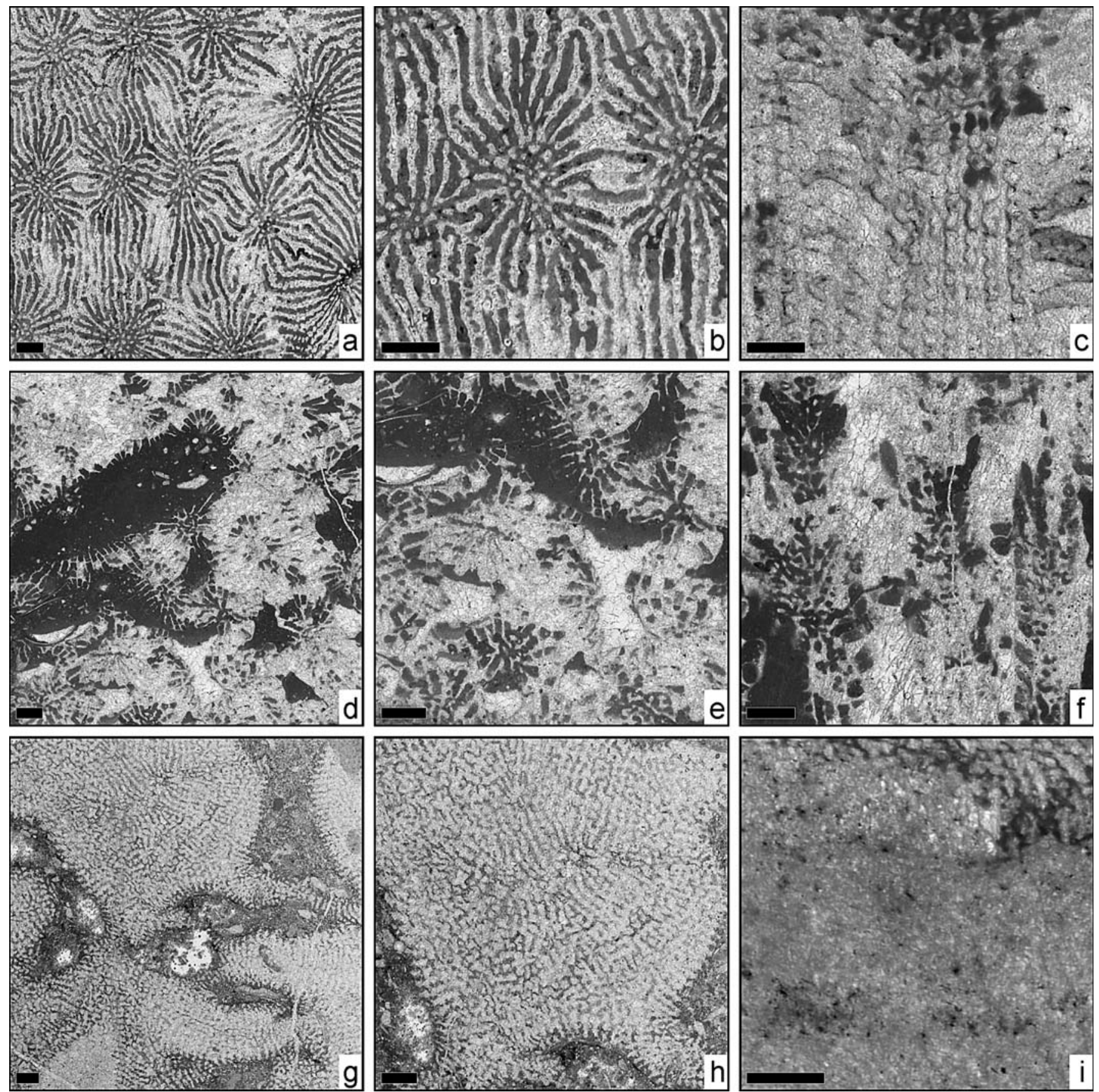

Figure 7. a-c) Dimorphastrea sp. (BSPG 2014 XV 26); (a) transversal thin section; (b) transversal thin section, detail; (c) longitudinal thin section. d-f) Ovalastrea picteti (Koby, 1897), (BSPG 2014 XV 29); (d) transversal thin section; (e) transversal thin section, detail; (f) longitudinal thin section. g-i) Dimorpharaea sp. (BSPG 2014 XV 32); (g) transversal thin section; (h) transversal thin section, detail; (i) longitudinal thin section. Scale bar $1 \mathrm{~mm}$.

Description. Plocoid colony. Calicular outline circular to elliptical. Septa perforated at their inner margin, in cross section slightly thicker close to the wall, becoming slightly thinner towards the centre. Symmetry of septa irregularly radial, but size orders can be distinguished that differs more by length than by thickness. Half of all septa extended to the calicular centre. Septa occasionally connected to each other close to the centre of the calice. Septal distal margin unknown, lateral face with pennulae and thorns, inner margin smooth. Pali or paliform lobes absent. Costae present, sub-confluent to non-confluent. Synapticulae present, occasional, mainly in the space between calices. Columella composed of isolated trabeculae or one more solid element. Endotheca consists of thin tabulae. Wall subcompact, parathecal. Coenosteum medium broad, consists of costae. Budding extracalicinal. 
Occurrence. Sierra del Carche, Late Albian, bed C3.

Other occurrences. Barremian of France (Doubs) Morteau. Late Aptian of Japan (Iwate-ken) Miyako-shi, Sakiyama, Hideshima and Shimohei-gun, Tanohata-mura, Haipe (TUM 59183). Early Late Albian (Inflatum zone) of Spain (Valencia, Alicante) Sierra de Llorençá.

Family Microsolenidae Duncan, 1884

Dimorpharaea de Fromentel, 1861 1860.

Type species. Microsolena koechlini Milne Edwards,

$$
\begin{gathered}
\text { Dimorpharaea } \mathrm{sp} . \\
\text { (Figs } 7 \mathrm{~g}-\mathrm{i})
\end{gathered}
$$

Material. BSPG 2014 XV 32; 2 thin sections.

\section{Dimensions.}

(2014 XV 32)

$\begin{array}{ll}\mathrm{cd} & 1.9-2.1 \\ \mathrm{cdw} & 1.5-2.3 \\ \mathrm{~s} & 15-16 \\ \mathrm{sd} & 8 / 2 \mathrm{~mm}\end{array}$

Description. Thamnasterioid colony with calices arranged in rows. Septa regularly perforated. Microstructure of large trabeculae. Septa in cross section equal in thickness in the whole septum. No septal symmetry. Half of all septa extended to the calicular centre. Septa occasionally connected to each other close to the centre of the calice. Septal distal margin with large regular granules, lateral face with pennulae, inner margin smooth. Pali or paliform lobes absent. Costae present, confluent, with thick granules on their surface. Synapticulae present, abundant. Columella small, substyliform. Endotheca unknown. Wall absent. Coenosteum poorly defined because of the type of the calicular arrangement. Budding intracalicinal, polystomodeal and complete.

Remarks. This material is very questionable and may be also related to Comoseris, Eocomoseris and Maeandraraea.

Occurrence. Sierra del Carche, Early Aptian, bed C1.

Suborder STYLININA Alloiteau, 1952

Family Cyathophoridae Duncan, 1884

Cryptocoenia Orbigny, 1849

Type species. Astrea alveolata Goldfuss, 1826.

Cryptocoenia almerai (d'Angelis d'Ossat, 1905)

(Figs 8a-c)
Material. BSPG 2014 XV 33; 1 thin section.

Synonymy.

v 1884 Columnastraea cf. striata Gldf. sp.; Toula, p. 1317, Pl. 6, Fig. 5

v 2013 Cryptocoenia almerai (d'Angelis d'Ossat, 1905); Löser, p. 31, Fig. 101 [here more detailed synonymy and occurrence data]

\section{Dimensions.}

$\begin{array}{lcccccc}(2014 X V 33) & \mathrm{n} & \min -\max & \mu & \mathrm{s} & \mathrm{cv} & \mu \pm \mathrm{s} \\ \mathrm{cl} & 9 & 1.04-1.43 & 1.23 & 0.15 & 12.2 & 1.08-1.38 \\ \mathrm{~s} & 6+6 & & & & & \end{array}$

Description. Plocoid colony. Calicular outline circular. Septa compact. Symmetry of septa radial and regularly hexameral. Cycles of septa subregular. Septal cycles differ in length. Septa short, not connected to each other. Septal lateral face smooth, inner margin smooth. Pali or paliform lobes absent. Costae unknown. Synapticulae and columella absent. Endotheca consists of tabulae. Wall compact, probably parathecal. Coenosteum narrow, consists of costae and tabulae. Budding extracalicinal.

Occurrence. Sierra del Carche, Late Albian, bed C4.

Other occurrences. See Löser (2013).

\section{Cryptocoenia sp.}

(Figs 8d-f)

Material. BSPG 2014 XV 34, 35; 3 thin sections.

Synonymy.

v 1996 Heterocoenia sp.; Baron-Szabo \& Steuber, p. 18

\section{Dimensions.}

$\begin{array}{lcccccc}(2014 \text { XV 35) } & \mathrm{n} & \min -\max & \mu & \mathrm{s} & \mathrm{cv} & \mu \pm \mathrm{s} \\ \mathrm{cl} & 30 & 1.25-1.81 & 1.48 & 0.14 & 9.7 & 1.34-1.62 \\ \mathrm{ccd} & 30 & 1.59-2.40 & 2.01 & 0.21 & 10.6 & 1.79-2.22 \\ \mathrm{~s} & 6 & & & & & \end{array}$

Description. Plocoid colony. Calicular outline circular. Septa compact. Symmetry of septa radial and regularly hexameral. Cycles of septa subregular. Septal cycles differ in length. Septa short, not connected to each other. Septal lateral face smooth, inner margin smooth. Pali or paliform lobes absent. Costae present, confluent or sub-confluent. 

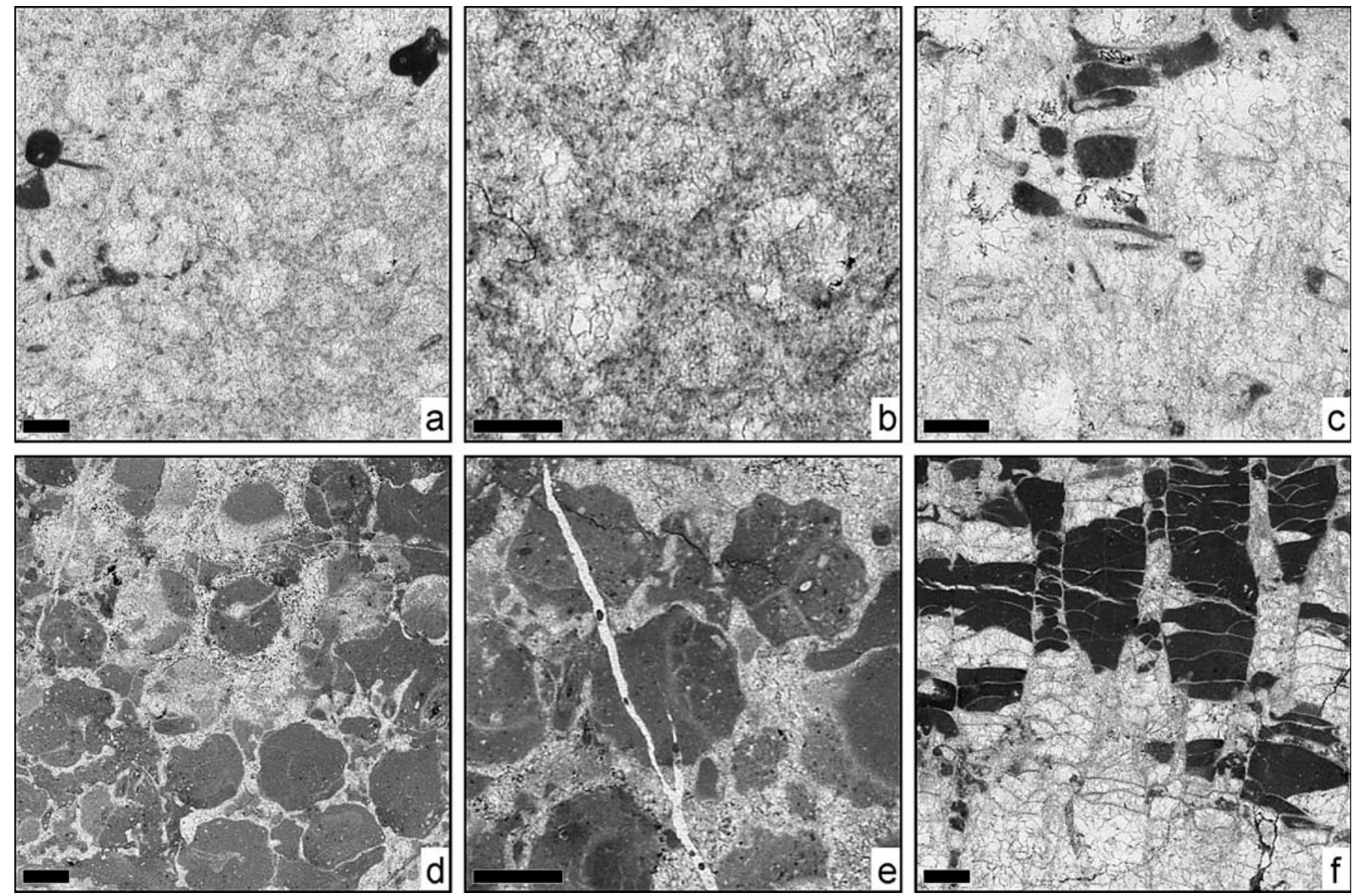

Figure 8. a-c) Cryptocoenia almerai (d'Angelis d'Ossat, 1905), (BSPG 2014 XV 33); (a) transversal thin section; (b) transversal thin section, detail; (c) longitudinal thin section. d-f) Cryptocoenia sp. (BSPG 2014 XV 35); (d) transversal thin section; (e) transversal thin section, detail; (f) longitudinal thin section. Scale bar $1 \mathrm{~mm}$.

Synapticulae and columella absent. Endotheca consists of regular tabulae and occasional dissepiments. Wall compact, parathecal. Coenosteum narrow, consists of costae and tabulae. Budding extracalicinal.

Remarks. This species differs from C. almerai by larger calicular dimensions and only six septa.

Occurrence. Sierra del Carche, Late Albian, bed C4.

Other occurrences. Early Aptian of Greece (Viotía) Arachova; Levadia, Perachorion (BSPG 2003 XX 5768). Aptian to Early Albian of Japan (Iwate-ken) Miyakoshi, Sakiyama, Hideshima (TUM L-NN-10). Late Aptian of Japan (Miyagi-ken) (TUM L-NN-9). Early Albian of Mexico (Sonora) Municipio Cucurpe, Cucurpe, La Mesa (ERNO L-4283) and Municipio Opodepe, Tuape, Cerro de la Espina (ERNO L-4260). Early Cenomanian of Greece (Kozani) Kozani, Nea Nikopolis (ERNO L-5883).

Family Stylinidae Orbigny, 1851

Stylina Lamarck, 1816
Type species. Stylina echinulata Lamarck, 1816.

Stylina inwaldensis (Ogilvie, 1897)

(Figs 3h-i)

Material. BSPG 2014 XV 36; 1 thin section.

\section{Synonymy.}

v 1897 Diplocoenia inwaldiensis; Ogilvie, p. 165, Pl. 18, Figs. 7,8

v 2013c Stylina inwaldiensis (Ogilvie, 1897); Löser et al., p. 66, Pl. 9, Figs. 10-12 [here more detailed synonymy and occurrence data]

\section{Dimensions.}

$\begin{array}{lcccccc}(2014 \text { XV 36) } & \mathrm{n} & \min -\max & \mu & \mathrm{s} & \mathrm{cv} & \mu \pm \mathrm{s} \\ \mathrm{cl} & 30 & 0.93-1.19 & 1.07 & 0.06 & 5.9 & 1.01-1.13 \\ \mathrm{ccd} & 30 & 1.18-1.94 & 1.61 & 0.17 & 10.6 & 1.43-1.78 \\ \mathrm{~s} & 8+8 & & & & & \end{array}$




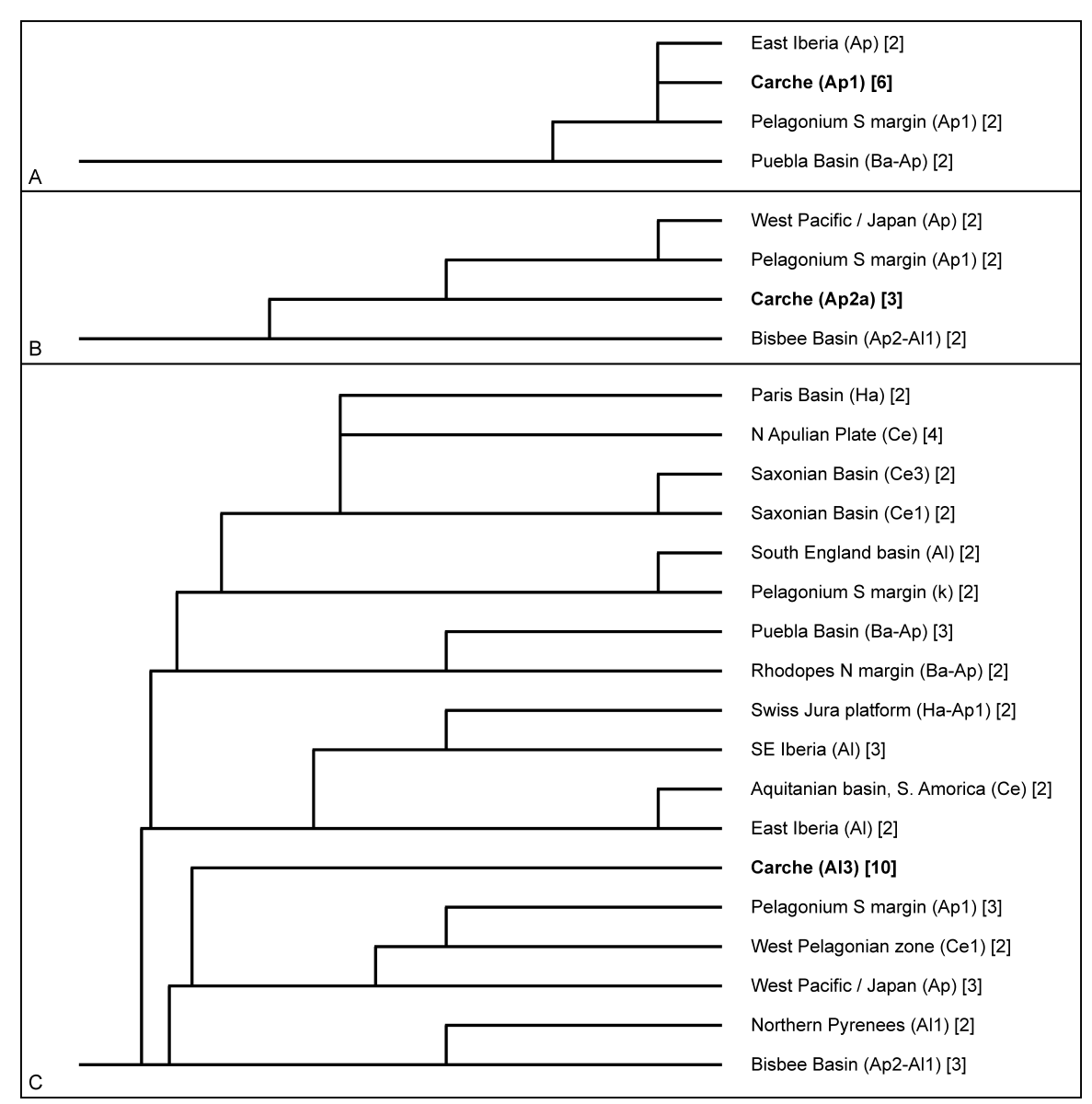

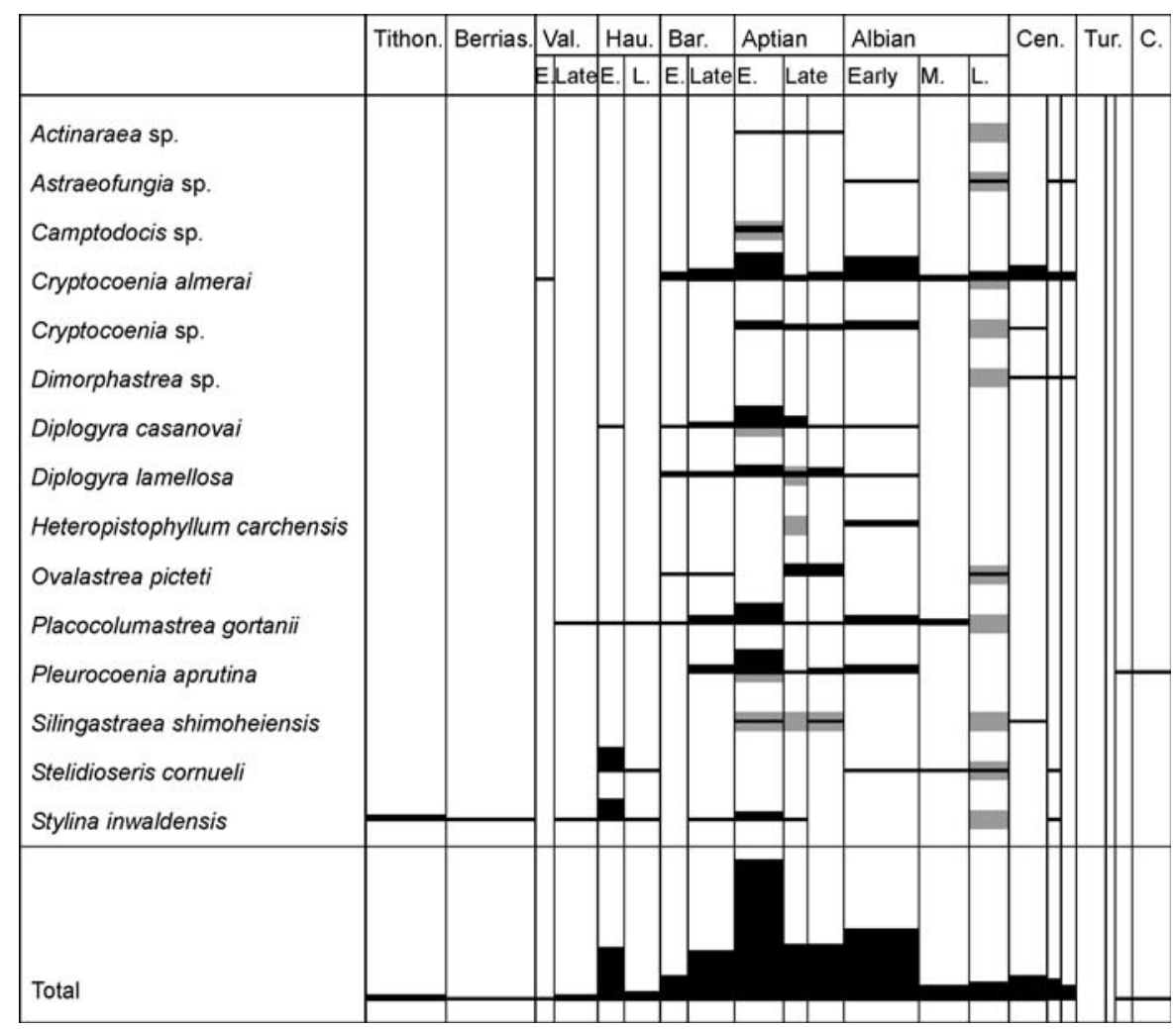

Figure 9. Correlation of faunules with joint species of the three coral bearing levels. Faunules with less than two joint species are omitted. Species number in brackets. The Correlation Ratio coefficient was applied. For details of calculation see Löser \& Minor (2007). A, Early Aptian; B, Late Aptian; C, Late Albian.

Figure 10. Stratigraphic distribution and commonness of species of the studied faunas. The thickness of the bars indicates the number of localities in which the species concerned was found until present. Grey bar indicates age level of the corresponding faunas. Below, the distributions are summarized. Ranges based on Löser et al. (2002, 2005); localities with a range longer than 13.3 ma are omitted from calculations, as well as localities with an uncertain stratigraphy. 
Description. Plocoid colony. Calicular outline circular. Septa compact, in cross section thin in the whole septum. Symmetry of septa radial and irregularly octameral. Cycles of septa subregular. Septal cycles differ in length and thickness. First septal cycle reaches $35 \%$ of the calicular diameter, those of the second cycle are shorter. Septa not connected to each other. Septal distal margin unknown, lateral face smooth (probably due to preservation), inner margin with auriculae. Pali or paliform lobes absent. Costae unknown. Synapticulae absent. Columella styliform. Endotheca unknown. Wall compact, probably parathecal. Coenosteum narrow. Constitution of the coenosteum unknown. Budding extracalicinal.

Remarks. Stylina inwaldiensis is a very common species and has a very long range. It is found from the Latest Jurassic, throughout the whole Early Cretaceous, and in the Late Cretaceous up to the Middle Cenomanian.

Occurrence. Sierra del Carche, Late Albian, bed C4.

Other occurrences. See Löser et al. (2013c).

\section{DISCUSSION}

The the three levels with corals have yielded comparably species-poor faunas. A sample bias can be excluded since a high amount of material was collected, but a conservation bias may have had a considerable influence on the final faunal list. Nevertheless, conservation is always a problem in Cretaceous coral faunas. The original aragonite skeletons always experience loss in quality during the diagenetic process, less if the $\mathrm{pH}$ of the sediments is high (marls as in the Gosau area, Austria, or ophiolitic conglomerates as in Greece and the Arabian Peninsula), more if the $\mathrm{pH}$ is low (e.g., pure carbonate rocks). The three faunas encompass typical Cretaceous coral genera. There are very common genera such as Astraeofungia, Cryptocoenia, Diplogyra, Dimorpharaea, Dimorphastrea, Ovalastrea, Placocolumastrea, Stelidioseris, less common genera (Actinaraea, Amphiastrea, Camptodocis, Pleurocoenia, Stylina) and two rather rare genera (Heteropistophyllum, Silingastraea). Particularly, the rare genera were already found in the Prebetic in other localities (Löser et al., 2013a). The distribution among Scleractinian suborders is comparable to other faunas (see for instance Löser, 2013): Faviina and Microsolenina are dominating, Archeocaeniina, Fungiina, Heterocoeniina, and Stylinina are subordinated, because they have simply less genera in the Cretaceous.

The three levels share only two genera (Diplogyra in $\mathrm{C} 1$ and $\mathrm{C} 2$; Silingastraea in all levels), although all genera (except for Amphiastrea that has its last occurrence in the
Early Aptian) has long ranges and are all present in the observed time span. The three coral faunas are small and therefore make a palaeobiogeographical comparison with other faunas difficult (Fig. 9). It is surprising that most correlating faunules have almost the same age as the observed Aptian faunas (Figs 9A-B). The more speciesrich Late Albian fauna shows also relationships to some Early Cretaceous faunules, but strong relationships to other Albian and to Cenomanian faunas (Fig. 9C). Most species do not experience range extensions (Fig. 10); only Actinaraea sp., and Placocolumastrea gortanii. All other species are known either from localities of the same age or younger and older sediments. The latter is mostly the case for the Late Albian fauna. Late Albian coral faunas are very poorly reported on a global scale and their faunal inventory is not well known (see Löser et al., 2013a for discussion). The total distribution pattern for all species corresponds of course to the global coral diversity (Löser et al., 2013a, Fig. 1); a very high diversity in the Early Aptian and a stepwise decrease from the Late Aptian on.

\section{ACKNOWLEDGEMENTS}

We would like to thank Jean-Pierre Masse (Marseille) for his help in fossil determination that assisted much to precise the stratigraphy. Financial support for sample preparation by UNAM/DGAPA PAPIIT project IN101111 for HL is greatly acknowledged. Additional thin sections were prepared in the ERNO laboratory by Aimee Orcí (Hermosillo, Sonora, Mexico). Reviews by Francisco Sánchez-Beristáin (Mexico City) and D.G. Pandey (Jaipur) helped to improve the article. Grammatical correction was undertaken by Matthew Copley (Kingston, Surrey, UK).

\section{REFERENCES}

Alloiteau, J. 1952. Embranchement des coelentérés. In: Traité de Paléontologie (ed. Piveteau, J.). Masson, Paris, 376-684.

Angelis d'Ossat, G. de 1905. Coralli del Cretacico inferiore della Catalogna. Palaeontographia Italica, 9, 169-251.

Baron-Szabo, R.C. 1993. Korallen der höheren Unterkreide („Urgon“) von Nordspanien (Playa de Laga, Prov. Guernica). Berliner geowissenschaftliche Abhandlungen, (E), 9, 147-181.

Baron-Szabo, R.C. 1997. Die Korallenfazies der ostalpinen Kreide (Helvetikum: Allgäuer Schrattenkalk; Nördliche Kalkalpen: Brandenberger Gosau) Taxonomie, Palökologie. Zitteliana, 21, 3-97.

Baron-Szabo, R.C. \& González León, C. M. 2003. Late Aptian-Early Albian corals from the Mural Limestone 
of the Bisbee Group (Tuape and Cerro de Oro areas), Sonora, Mexico. Special Publications in Geology, 187-225.

Baron-Szabo, R.C. \& Steuber, T. 1996. Korallen und Rudisten aus dem Apt im tertiären Flysch des Parnass-Gebirges bei Delphi-Arachowa. Berliner geowissenschaftliche Abhandlungen, (E), 18, 3-75.

Beauvais, M. 1974. Le nouveau sous-ordre des Heterocoeniida. Cnidaires fossiles (= Fossil Cnidaria), 3, 2, 22-23.

Chacón, B. \& Martín-Chivelet, J. 2003. Discontinuidades estratigráficas regionales en las series hemipelágicas finicretácicas del Prebético (sector Jumilla-Callosa-Aspe). Journal of Iberian Geology, 29, 89-108.

Cottreau, J. 1935. Types du prodrome de paléontologie stratigraphique universelle (11). Annales de Paléontologie, 24, 37-52.

Deloffre, R. 1961. Sur la découverte d'un nouveau lituolidé du Crétacé des Basses-Pyrénées: Pseudochoffatella cuvillieri n. gen., n. sp. Revue de Micropaléontologie, 4, 105-107.

Dietrich, W.O. 1926. Steinkorallen des Malms und der Unterkreide im südlichen Deutsch-Ostafrika. Palaeontographica (suppl.7), 1, 43-62.

Douvillé, H. 1912. Les Orbitolines et leur echaînements. Comptes rendus hebdomadaires des séances de l'Académie des Sciences, 155, 13, 567-572.

Duncan, P.M. 1870. A monograph of the British fossil corals $(2,2)$ : Corals from the Upper Greensand of Haldon, from the Gault, and the Lower Greensand. Palaeontographical Society monographs, 23, 27-46.

Duncan, P.M. 1884. A revision of the families and genera of the sclerodermic Zoantharia Edwards et Haime, or Madreporaria (M. Rugosa excepted) (1-4). Journal of the Linnean Society of London, Zoology, 18, 104-105, 1-204.

Eguchi, M. 1936. Three new genera of corals from the Lower Cretaceous of Japan. Proceedings of the Imperial Academy of Japan (= Teikoku-Gakushiin), 12, 3, 70-72.

Eguchi, M. 1951. Mesozoic hexacorals from Japan. Science Reports of the Tohoku Imperial University, (2: Geology), 24, 1-96.

Etallon, A. 1859. Études paléontologiques sur le HautJura. Rayonnés du Corallien. Mémoires de la Société d'émulation du département du Doubs, (3), 3, 401-553.

Fromentel, E. 1857. Description des polypiers fossiles de l'étage Néocomien. Bulletin de la société des sciences historiques et naturelles de l'Yonne, 1-78.

Fromentel, E. 1861. Introduction à l'étude des polypiers fossiles. Mémoires de la Société d'émulation du Doubs, (3), 5, 1-357.

Goldfuss, A., 1826. Petrefacta Germaniae $(1,1)$. Arnz, Düsseldorf.

Goldfuss, A. 1829. Petrefacta Germaniae (1, 2). Arnz, Düsseldorf.

Hackemesser, M. 1936. Eine kretazische Korallenfauna aus Mittel-Griechenland und ihre paläobiologischen Beziehungen. Palaeontographica, (A), 84, 1-97.

Koby, F. 1888. Monographie des polypiers jurassiques de la Suisse (8). Abhandlungen der Schweizerischen Paläontologischen Gesellschaft, 15, 401-456.
Koby, F. 1897. Monographie des polypiers crétacés de la Suisse (2). Abhandlungen der Schweizerischen Paläontologischen Gesellschaft, 23, 29-62.

Kolodziej, B., Ivanov, M. \& Idakieva, V. 2012. Prolific development of pachythecaliines in Late Barremian, Bulgaria: coral taxonomy and sedimentary environment. Annales Societatis Geologorum Poloniae, 82, 291-330.

Lamarck, J.B.P. 1816. Histoire naturelle des animaux sans vertèbres (2). Verdière, Paris.

Liao, Wei-hua 1982. Mesozoic scleractinian corals from Xizang (Tibet). Paleontology of Xizang (Tibet), 4, 151-183.

Löser, H. 2004. PaleoTax - a database program for palaeontological data. Computer \& Geosciences, 30, 5, 513-521.

Löser, H. 2010. The Barremian coral fauna of the Serre de Bleyton mountain range (Drôme, France). Annalen des Naturhistorischen Museums in Wien, 112, 575-612.

Löser, H. 2012. Intraspecific variation in the genus Stelidioseris (family Actinastraeidae, suborder Archeocaeniina, order Scleractinia; Jurassic-Cretaceous). Geologica Belgica, 15, 4, 382-387.

Löser, H. 2013. An Early Albian shallow marine coral fauna from Southern France - insight into evolution and palaeobiogeography of Cretaceous corals. Palaeobiodiversity and Palaeoenvironments, 93, 1, 1-43.

Löser, H., Castro, J.M. \& Nieto, L.M. 2013a. Late Albian Scleractinian corals from the Prebetic Zone (SE Spain). Palaeontographica, 301, 1/2, 1-62.

Löser, H. \& Ferry, S. 2006. Coraux du Barrémien du Sud de la France (Ardèche et Drôme). Geobios, 39, 4, 469-489.

Löser, H., Stemann, Th.A. \& Mitchell, S.F. 2009. Oldest Scleractinian fauna from Jamaica (Hauterivian, Benbow Inlier). Journal of Paleontology, 83, 3, 333-349.

Löser, H., Vilas, L., Arias, C., Ruiz-Ortiz, P.A., Castro, J.M. \& Gea, G.A. de 2013b. An Early Aptian coral fauna from the Prebetic (Southern Spain). Spanish Journal of Palaeontology, 28, 2, 193-214.

Löser, H., Werner, W. \& Darga, R. 2013c. A Middle Cenomanian coral fauna from the Northern Calcareous Alps (Bavaria, Southern Germany) - new insights into the evolution of Mid-Cretaceous corals. Zitteliana, A53, 37-76.

Martín-Chivelet, J. 1993. Las Plataformas Carbonatadas del Cretácico superior de la Margen Bética (Altiplano de Jumilla-Yecla, Murcia). Col. Tesis doctorales, 238/93. Universidad Complutense de Madrid.

Martín-Chivelet, J. 1994. Litoestratigrafía del Cretácico superior del Altiplano Jumilla-Yecla (Zona Prebética). Cuadernos de Geología Ibérica, 18, 117-173.

Martín-Chivelet, J., Berasategui, X., Rosales, I., Vilas, L., Vera, J.A., Caus, E., Gráfe, K.U., Mas, R., Puig, C., Segura, M., Robles, S., Floquet, M., Quesada, S., RuizOrtiz, P.A., Frenegal-Martínez, M.A., Salas, R., García, A., Martín-Algarra, A., Arias, C., Meléndez, M., Chacón, B., Molina, J.M., Sanz, J.L., Castro, J.M., García-Hernández, M., Carenas, B., García-Hidalgo, J., Gil, J. \& Ortega, F. 2002. Cretaceous. In: The Geology of Spain (eds. Gibbons, W. \& Moreno, T.). The Geological Society, London, 255-292. 
Martín-Chivelet, J. \& Chacón, B. 2007. Event-stratigraphy of the upper Cretaceous to lower Eocene hemipelagic sequences of the Prebetic Zone (SE Spain): record of the onset of tectonic convergence in a passive continental margin. Sedimentary Geology, 197, 141-163.

Martínez del Olmo, W., Leret, G. \& Megías, A.G. 1982. El límite de la plataforma carbonatada del Cretácico superior en la zona Prebética. Cuadernos de Geología Ibérica, 8 , 597-614.

Masse, J.P., Arias, C. \& Vilas, L. 1992. Stratigraphy and biozonation of a reference Aptian-Albian p.p. Tethyan carbonate platform succession: The Srra. del Carche series (Oriental Prebetic Zone-Murcia, Spain). In: New Aspects on Tethyan Cretaceous Fossil Assemblages. Springer Verlag, Berlin, 201-221.

Matthews, S.C. 1973. Notes on open nomenclature and on synonymy lists. Palaeontology, 16, 4, 713-719.

Michelin, H., 1841. Iconographie zoophytologique. Description par localités et terrains des polypiers fossiles de France (1). Bertrand, Paris.

Milne Edwards, H., 1860. Histoire naturelle des coralliaires ou polypes proprement dits (3, Atlas). Librairie encyclopédique de Roret, Paris.

Morycowa, E. 1964. Hexacoralla des couches de Grodziszcze (Néocomien Carpathes). Acta Palaeontologica Polonica, 9, 1, 1-114.

Morycowa, E. 1971. Hexacorallia et Octocorallia du Crétacé inférieur de Rarau (Carpathes orientales roumaines). Acta Palaeontologica Polonica, 16, 1-149.

Morycowa, E., Decrouez, D. \& Schenk, K. 1995. Présence de Latusastrea exiguis (Scléractiniare) dans le Schrattenkalk du Rawil (Helvétique, Suisse) et quelques remarques sur les espèces crétacées de genre Latusastrea Orbigny, 1849. Annales Societatis Geologorum Poloniae, 64, 15-22.

Morycowa, E. \& Roniewicz, E. 1995. Microstructural disparity between Recent fungiine and Mesozoic microsolenine scleractinians. Acta Palaeontologica Polonica, 40, 4, 361-385.

Moullade, M. \& Peybernès, B. 1978. Un nouvel Orbitolinidé du Gargasien supérieur (Aptien supérieur) des Pyrénées, Orbitolinopsis reticulata n. sp. Geobios, 11, 4, 493-503.

Ogilvie, M.M. 1897. Die Korallen der Stramberger Schichten. Palaeontographica, (suppl.2), 7, 74-282.

Orbigny, A. 1849. Note sur les polypiers fossiles. Masson, Paris.

Orbigny, A. 1850. Prodrôme de Paléontologie stratigraphique universelle des animaux mollusques et rayonnés (1-2). Masson, Paris.

Orbigny, A. 1851. Cours élémentaire de Paléontologie (3): Polypiers ou Zoophytes. Masson, Paris.

Prever, P.L. 1909. Anthozoa. La fauna coralligena del Cretaceo dei Monti d'Ocre nell'Abruzzo Aquilano. Memorie descrittive della carta geologica d'Italia, 5, 1, 51-147.

Reig Oriol, J. 1989. Sobre varios géneros y especies de escleractinias fósiles del Cretácico Catalán. Privately published, Barcelona.

Reig Oriol, J. 1994. El género Eugyra en el Cretáceo del nordeste español. Batalleria, 4, 31-36.
Schroeder, R. \& Poignant, A. 1964. Orbitolinopsis aquitanica, eine neue Foraminifere der Unterkreide der Aquitaine (SW-Frankreich). Eclogae Geologicae Helvetiae, 57, 2, 553-557.

Schroeder, R. 1965. Neorbitolinopsis n. gen. und ihre systematische Position innerhalb der Orbitoliniden. Eclogae Geologicae Helvetiae, 58, 1, 579-589.

Sikharulidze, G.Ya. 1985. [Hexacorals from the Urgonian facies of the Dzirul Massif and its northern frame.] Trudy Akademija Nauk Gruzinskoj SSR, Geologiceskij Institut, 59, 1-110.

Tomes, R.F. 1893. Observations on the affinities of the genus Astrocoenia. Quarterly Journal of the Geological Society of London, 49, 569-573.

Toula, F. 1884. Geologische Untersuchungen im westlichen Theile des Balkans und in den angrenzenden Gebiete (10): Von Pirot nach Sofia auf den Vitos, über Pernik nach Trn und über Stol nach Pirot. Sitzungsberichte der MathematischNaturwissenschaftliche Classe der Kaiserlichen Akademie der Wissenschaften, (1), 88, 1279-1348.

Turnšek, D. \& Buser, S. 1976. Knidarijska favna iz senonijske brece na Banjski Planoti. Razprave Slovenska akademija znanosti in umetnosti, 19, 3, 37-88.

Vaughan, T.W. 1905. A critical review of the literature of the simple genera of Fungida, with a tentative classification. Proceedings of the United States National Museum, 28, 1401, 371-424.

Vaughan, T.W. \& Wells, J.W. 1943. Revision of the suborders, families and genera of Scleractinia. Special Papers. Geological Society of America, 44, 1-363.

Verrill, A.E. 1868-70. Notes on the Radiata in the museum of Yale College, with descriptions of new genera and species. No. 6. Review of the corals and polyps of the West Coast of America. Transactions of the Connecticut Academy of Arts and Sciences, 1, 2, 377-567.

Vilas, L. (Coord.), Castro, J.M., Martín-Chivelet, J., Company, M., Ruiz-Ortiz, P.A., Arias, C., Chacón, B., de Gea, G.A. \& Estévez, A. 2004. El Prebético del Sector Oriental. In: Geología de España (ed. Vera, J.A.), SGE-IGME, Madrid, 361-363.

Vilas, L., Martín-Chivelet, J. \& Arias, C. 2003. Integration of subsidence and sequence stratigraphic analyses in the Cretaceous carbonate platforms of the Prebetic (Jumilla-Yecla Region), Spain. Palaeogeography, Palaeoclimatology, Palaeoecology, 200, 107-129.

Vilas, L., Martín-Chivelet, J., Arias, C., Chacón, B., Rodríguez Estrella, T., García del Cura, MaA. \& Rodríguez-García, M.A., 2005. Enciclopedia divulgativa de la Historia Natural de Jumilla-Yecla, 6, Geología. SOMEH, Jumilla.

Vilas, L., Martín-Chivelet, J., Arias, C., Giménez, R., RuizOrtiz, P.A. Castro, J.M. Masse, J.P. \& Estévez, A. 1998. Cretaceous carbonate platforms of the Spanish Levante. Sedimentary evolution and sequence stratigraphy. In: 15th IAS International Sedimentological Congress, Field trip Guide Book, 293-315.

Wells, J.W. 1932. Corals of the Trinity Group of the Commanchean of central Texas. Journal of Paleontology, $6,3,225-256$. 
